\title{
Interactions Between the Nocturnal Low-Level Jets and the Urban Boundary Layer: A Case Study over London
}

\author{
Aristofanis Tsiringakis $^{1,2}$ (D) Natalie E. Theeuwes ${ }^{1,3_{(D)}} \cdot$ Janet F. Barlow ${ }^{3}$ (D) \\ Gert-Jan Steeneveld ${ }^{2}$
}

Received: 25 January 2021 / Accepted: 18 November 2021 / Published online: 1 January 2022

(c) The Author(s) 2021

\begin{abstract}
Understanding the physical processes that affect the turbulent structure of the nocturnal urban boundary layer (UBL) is essential for improving forecasts of air quality and the air temperature in urban areas. Low-level jets (LLJs) have been shown to affect turbulence in the nocturnal UBL. We investigate the interaction of a mesoscale LLJ with the UBL during a 60-h case study. We use observations from two Doppler lidars and results from two high-resolution numerical-weather-prediction models (Weather Research and Forecasting model, and the Met Office Unified Model for limited-area forecasts for the U.K.) to study differences in the occurrence frequency, height, wind speed, and fall-off of LLJs between an urban (London, U.K.) and a rural (Chilbolton, U.K.) site. The LLJs are elevated $(\approx 70 \mathrm{~m})$ over London, due to the deeper UBL, while the wind speed and fall-off are slightly reduced with respect to the rural LLJ. Utilizing two idealized experiments in the WRF model, we find that topography strongly affects LLJ characteristics, but there is still a substantial urban influence. Finally, we find that the increase in wind shear under the LLJ enhances the shear production of turbulent kinetic energy and helps to maintain the vertical mixing in the nocturnal UBL.
\end{abstract}

Keywords Urban boundary layer · Doppler lidar · Low-level jet · London · Weather research and forecasting model

Gert-Jan Steeneveld

gert-jan.steeneveld@wur.nl

Aristofanis Tsiringakis

aristofanis.tsiringakis@knmi.nl

Natalie E. Theeuwes

natalie.theeuwes@knmi.nl

Janet F. Barlow

j.f.barlow@reading.ac.uk

1 Royal Netherlands Meteorological Institute (KNMI), De Bilt, The Netherlands

2 Meteorology and Air Quality Section, Wageningen University and Research, Wageningen, The Netherlands

3 Department of Meteorology, University of Reading, Reading, UK 


\section{Introduction}

Urban boundary layers (UBLs) differ substantially in their depth and vertical structure from their rural counterparts (Pal et al. 2012; Barlow 2014) due to differences in the surface energy balance (Arnfield 2003; Barlow et al. 2015). Nocturnal UBLs exhibit increased turbulent mixing due to greater turbulence kinetic energy (TKE, variable notation as $e$ ) produced from buoyancy, the nocturnal release of heat stored in buildings during daytime, anthropogenic activities, and increased surface drag. Increased turbulent mixing over cities may delay the collapse of the UBL after sunset and result in a deeper nocturnal UBL (Pal et al. 2012). Lowlevel jets (LLJs) have the potential to affect vertical mixing in the nocturnal UBL (Lundquist and Mirocha 2008; Barlow et al. 2015). Unravelling the physical processes that affect the nocturnal production of TKE is essential to better understand and represent the evolution of the nocturnal UBL, which can be beneficial for air quality and weather forecasts in cities.

Low-level jets are super-geostrophic wind-speed maxima that occur near the surface, usually at the top of the nocturnal boundary layer (Blackadar 1957; Baas et al. 2009). They are formed through: a) inertial oscillations due to the collapse of turbulent mixing after sunset (Blackadar 1957) and b) baroclinicity from local topographic differences or largescale synoptic forcing (Holton 1967; Kotroni and Lagouvardos 1993). Shapiro et al. (2016) unified both mechanisms and showed that their interaction leads to strong LLJs over the Great Plains in the U.S.A. Low-level jets are known to increase shear production of TKE (Banta et al. 2003, 2006; Wang et al. 2007; Lundquist and Mirocha 2008). Previous studies have employed in situ observations (i.e. Doppler lidar, sodar) (Banta et al. 2003; Wang et al. 2007; Baas et al. 2009; Kallistratova and Kouznetsov 2012; Barlow et al. 2015; Banakh and Smalikho 2018) and/or numerical models (i.e. numerical weather prediction, NWP, and large-eddy simulation, LES) (Storm et al. 2009; Park et al. 2014; Vanderwende et al. 2015) to study LLJs.

Many studies (Wang et al. 2007; Lemonsu et al. 2009; Kallistratova and Kouznetsov 2012; Klein et al. 2016) have found that the enhanced turbulent mixing and deeper nocturnal UBLs over urban areas can lead to elevated and slower LLJs compared to their rural counterparts (see Fig. 1). The relation between the nocturnal boundary-layer height and the LLJ height was also established by Pichugina and Banta (2010). Effects of LLJs on the depth of the nocturnal UBL and the intensity of urban heat islands have also been reported (Wang et al. 2007; Lundquist and Mirocha 2008; Hu et al. 2013). Barlow et al. (2015) suggested that LLJs can increase vertical mixing over urban areas and may form an 'upside-down' boundary layer, where vertical mixing is driven from the wind shear at the boundary-layer top. This hypothesis is also supported by several other studies that show increased shear production of TKE below the LLJ (Banta et al. 2003, 2006; Lundquist and Mirocha 2008; Banakh and Smalikho 2018). In terms of air quality, Hu et al. (2013) showed this downward mixing caused by the nocturnal LLJ enhances near-surface ozone concentrations. Moreover, urban areas are often located in areas of moderate topographic heterogeneity (hills, coast lines, etc.), where orographic effects (i.e. orographic gravity waves, gap flows, blocking, form drag) can affect the low-level flow. These orographic processes affect the vertical transport of momentum and turbulent mixing, and can thus influence LLJ formation (Banta et al. 2004).

Despite this progress, our understanding of the interaction between LLJs and complex urban morphology is still limited (Lundquist and Mirocha 2008; Barlow et al. 2015). Thus, in order to better understand how urban areas affect LLJs we investigate the interactions between LLJs and enhanced turbulent mixing over an urban area surrounded by moderate topographic features in and around London, U.K. Urban and non-urban effects on LLJ characteristics are 


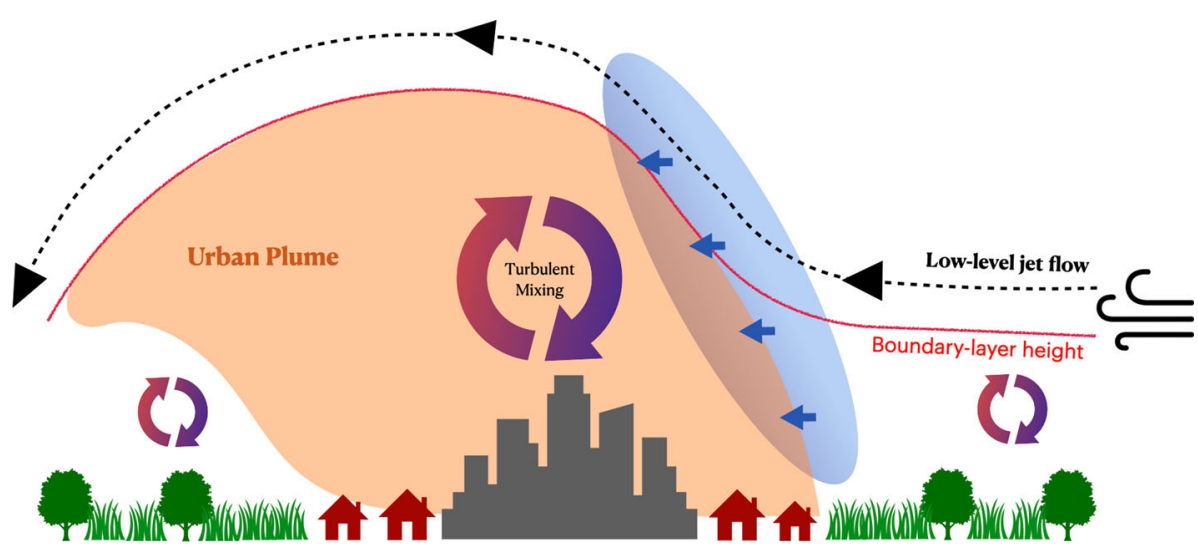

Fig. 1 Conceptual illustration of an LLJ's transition from a rural to an urban area and vice versa. The higher turbulent mixing over the urban area is indicated with the larger mixing arrows, while the area of the stronger turbulent mixing (urban plume) is coloured orange. The upwind urban area, where we expect the impact of momentum advection, is indicated with the blue shade and arrows

identified using both field measurements and NWP models. We also investigate the spatial variability of LLJ characteristics to identify whether the turbulent urban plume (Fig. 1) and the momentum advection from upwind rural areas affect the LLJs. Finally, LLJ effects on the shear production of TKE and turbulent mixing within the nocturnal UBL are identified.

Section 2 describes the methodology, while Sect. 3 presents the characterization of LLJs based on the Doppler lidar observations. An evaluation of both NWP models with respect to in situ Doppler lidar observations is conducted (Sect. 4), followed by the main analysis of LLJ differences between the two sites (Sect. 5). A spatial analysis of LLJ characteristics over London (Sect. 6) is followed by idealized experiments used to quantify non-urban (topographic, coastline etc.) effects on LLJ characteristics over London (Sect. 7), before the quantification of LLJs effects on vertical mixing in the UBL (Sect. 8), followed by a discussion (Sect. 9), and conclusions (Sect. 10).

\section{Methodology}

\subsection{Case Study Selection}

A 60-h period (0000 UTC 14 May 2019-1200 UTC 16 May 2019) is selected as the case study. The period is characterized by a high pressure system (Online Resources 2, 3), located over the North Sea, and easterly flow over south-east England with little cloud cover. During the case study the high pressure system moves to the north-east, inducing a decrease in baroclinicity during the second night (15-16 May 2019, Online Resource 3). This period was selected as it is one of the few periods with clearly defined LLJs detected over both Doppler lidar sites (London and Chilbolton) without frontal passages that could influence the LLJ formation and characteristics. 


\subsection{Model Description: Weather Research and Forecasting Model}

We use the advanced research Weather Research and Forecasting (WRF) model version 4.1 (Skamarock et al. 2019) with an outer domain (7.5 km horizontal grid spacing, $200 \times 200$ grid cells) and a one-way nested inner domain $(1.5 \mathrm{~km}$ horizontal grid spacing, $201 \times 201$ grid cells) centred over London (Fig. 2b). The model runs for a 60-h period, with the first $12 \mathrm{~h}$ considered as spin-up time. We use 90 vertical hybrid-eta grid levels up to $100 \mathrm{hPa}$, with increased vertical spacing near the surface (10 levels in the lowest $500 \mathrm{~m})$. Initial and boundary conditions are provided using the 6-h European Centre for Medium-Range Weather Forecasts (ECMWF) operational analysis at 10-km grid spacing.

In the outer domain, the surface and boundary layer are parametrized using the revised MM5 model (Jimenez et al. 2012) and Mellor-Yamada-Nakanishi-Niino (MYNN) level 2.5 (Mikio and Hiroshi 2009) parametrizations, which have been shown to perform well in recent LLJ studies (Kalverla et al. 2019a,b). Convection is parametrized using the Tiedtke parametrization (Zhang et al. 2011), while for microphysics the Thompson et al. (2008) parametrization is used. Shortwave and longwave radiation are parametrized using the Rapid Radiative Transfer Model (RRTMG) parametrization (Iacono et al. 2008). The urban surfaces are represented using the single-layer urban canopy model (SLUCM) (Kusaka et al. 2001; Chen et al. 2011) with the Noah land-surface model (Chen and Dudhia 2001) representing the vegetated land-surface processes.

The inner domain uses the same physics suite, with a few exceptions. The TKE advection and the eddy-diffusivity-mass-flux functionalities of the MYNN parametrization (Olson et al. 2019) are active in the inner domain, but not in the outer domain. No convection parametrization is used in the inner domain. The default urban WRF Moderate Resolution Imaging Spectroradiometer (MODIS) land-use class (LUC) is modified by adding two additional urban LUCs to better represent the urban morphology of London in the inner domain. The three dominant urban LUCs (low, middle, and high density urban areas) correspond to local climate zones (LCZs) 6, 5, and 2, with a spatial distribution and surface parameters following the World Urban Database and Access Portal Tools (WUDAPT) LCZ classification of London (https://wudapt.cs.purdue.edu/wudaptTools/default/getlcz). The maximum hourly anthropogenic heat flux in the WRF-SLUCM configuration is set to $15 \mathrm{~W} \mathrm{~m}^{-2}$ for LCZ 6, $35 \mathrm{~W} \mathrm{~m}^{-2}$ for LCZ 5, and $70 \mathrm{~W} \mathrm{~m}^{-2}$ for LCZ 2 at the centre of London and follows a diurnal cycle. The topography in the inner WRF domain is depicted in Fig. 2c.

\subsection{Model Description: High-Resolution Met Office U.K. Model}

The Met Office operational limited-area forecasts for the U.K. (UKV) runs use a limited area set-up with 70 vertical levels and a grid spacing of $1.5 \mathrm{~km}$ at the centre of the domain, which becomes more coarse towards the edges (Fig. 2a). A forecast is run every $3 \mathrm{~h}$ with a threedimensional variational (3D-VAR) data assimilation cycle. This study uses the 0900 UTC forecasts. The atmospheric turbulence is parametrized using a blending approach described by Boutle et al. (2014). The parametrization blends between a one-dimensional non-local boundary-layer parametrization by Lock et al. (2000) and a Smagorinsky-Lilly parametrization dependent on the turbulent length scale and the grid length. The land-surface exchange is parametrized using the JULES (Joint U.K. Land Environment Simulator; Best et al. 2011) tiling approach with 10 tiles. The radiation and fluxes from the urban tile are calculated using Met Office-Reading Urban Surface Exchange Scheme (MORUSES), which is a single-layer urban canyon parametrization (Harman et al. 2004; Porson et al. 2010). The MORUSES 


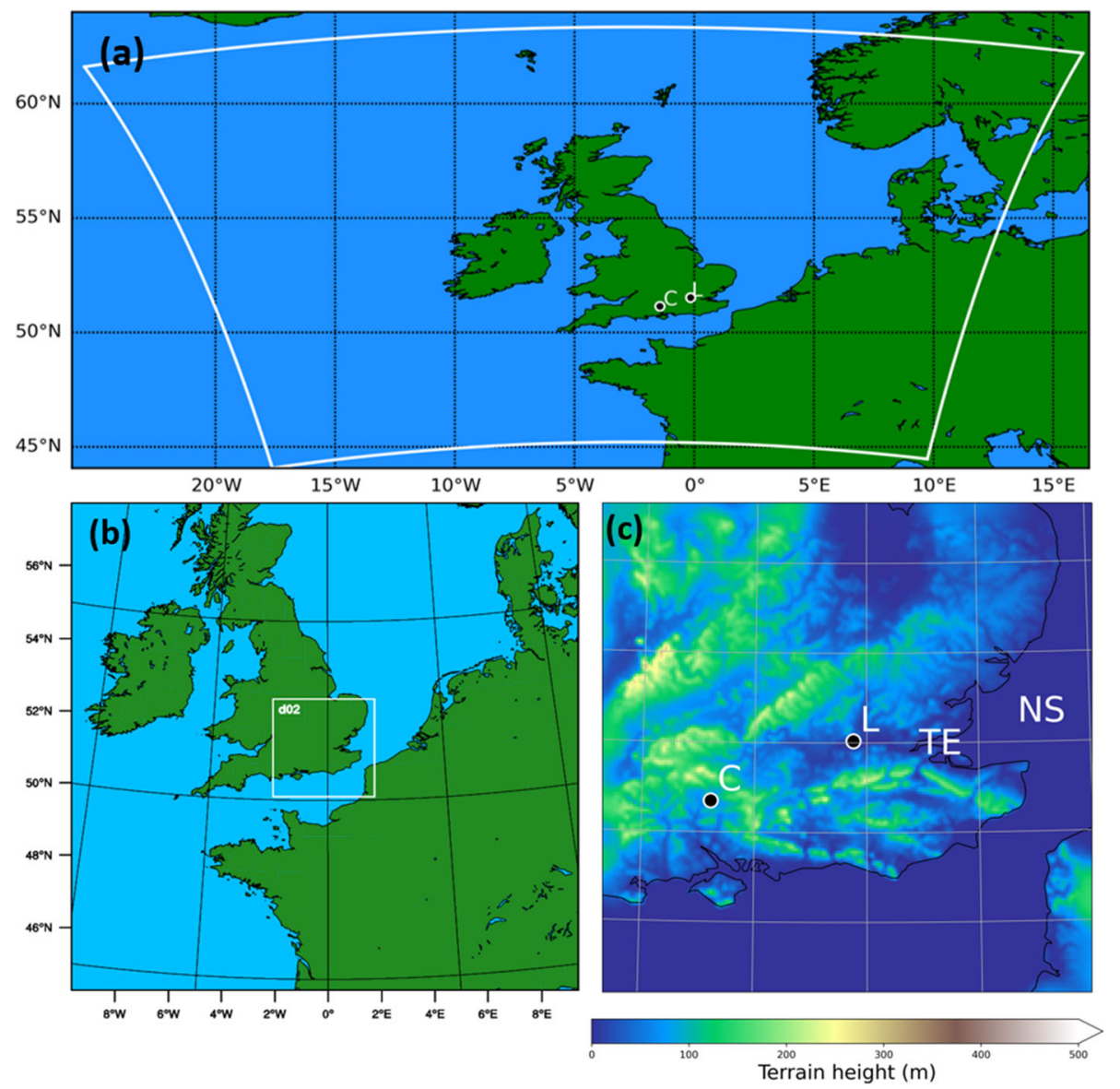

Fig. 2 Illustrations of a the model domain of the UKV model, $\mathbf{b}$ the outer (d01) and inner (d02) domains of the WRF model, and $\mathbf{c}$ the terrain height $(\mathrm{m})$ of the inner WRF model domain. The locations of the London and Chilbolton Doppler lidar sites, as well as the North Sea and Thames Estuary are designated with dots and a corresponding starting letter(s)

parametrization uses a temporally and spatially varying anthropogenic heat flux based on emission bases for London. For more information, we refer to Bohnenstengel et al. (2014). Finally, there is no shallow convection parametrization and the cloud parametrization by Smith (1990) is used.

\subsection{Doppler Lidar Observations}

Wind profiles are observed at two locations, one in the centre of London, and one at a rural site 100-km south-west of the London site (Table 1). In London, a 1.5- $\mu \mathrm{m}$ Doppler lidar (HALO Photonics Streamline, London, U.K.) is located at the London Southbank University (LSU) roof-top site $\left(51^{\circ} 29^{\prime} 53.4^{\prime \prime} \mathrm{N} ; 0^{\circ} 06^{\prime} 07.2^{\prime \prime} \mathrm{W}\right)$. The roof level is $36.5 \mathrm{~m}$ above sea level (a.s.l) and $33.5 \mathrm{~m}$ above ground level (a.g.l). The mean building height in a 1-km radius of the site is $12.8 \mathrm{~m}$, with a standard deviation of $9.5 \mathrm{~m}$. The London wind profiles are calculated using 
Table 1 Properties of the two Doppler lidars

\begin{tabular}{lll}
\hline & London & Chilbolton \\
\hline Type & 3, HALO Streamline & 118, HALO Streamline Pro \\
Wavelength & $1.5 \mu \mathrm{m}$ & $1.5 \mu \mathrm{m}$ \\
Pulse repetition rate & $20 \mathrm{kHz}$ & $10 \mathrm{kHz}$ \\
Range resolution & $18 \mathrm{~m}$ & $30 \mathrm{~m}$ \\
Maximum range & $3600 \mathrm{~m}$ & $9600 \mathrm{~m}$ \\
Focus Stare & $\infty$ & $\infty$ \\
Focus VAD 75 & $1000 \mathrm{~m}$ & $\infty$ \\
Lens diameter & $6 \mathrm{~cm}$ & $5 \mathrm{~cm}$ \\
\hline
\end{tabular}

a 6-point velocity azimuth display (VAD) scan at $75^{\circ}$ elevation, which occurs every 6 min. For both Doppler lidars, backscatter corrections and error estimates are calculated following Manninen et al. (2016, 2018) and Vakkari et al. (2019). Additional filtering to remove points with wind speed error larger than $1 \mathrm{~m} \mathrm{~s}^{-1}$. Then the data are averaged to 30-min intervals using five 6-min scans around the 30-min points (i.e., $\pm 15 \mathrm{~min}$ around the 0000 timestamp).

In Chilbolton, a 1.5- $\mu \mathrm{m}$ Doppler lidar (HALO Photonics Streamline Pro, Chilbolton, U.K.) is surrounded by grasslands $\left(51^{\circ} 08^{\prime} 40.2^{\prime \prime} \mathrm{N} ; 1^{\circ} 26^{\prime} 13.2^{\prime \prime} \mathrm{W}, 90 \mathrm{~m}\right.$ a.s.l). At this site, a 24-point VAD scan at $75^{\circ}$ elevation occurs every 10 min from which wind profiles are derived. The same backscatter corrections, error estimates, and filtering are used as in the London Doppler lidar. Three 10-min wind profiles are used to compute the 30-min values at each time step.

In between other scan patterns, the Doppler lidars operate in vertical stare mode, at an elevation angle of $90^{\circ}$ to measure the vertical velocity variance and derive the mixing height. This scan returns the vertical velocity component at a high temporal resolution, i.e. $0.5-0.625$ $\mathrm{Hz}$ for the London site and $0.048-0.055 \mathrm{~Hz}$ at Chilbolton. From the high-resolution vertical velocity data, higher-order statistics are calculated over time periods of $30 \mathrm{~min}$, i.e. variance, skewness, kurtosis. Data where the signal-to-noise ratio $(\mathrm{SNR})$ is low $(S N R+1<1.01)$ are excluded. In order to compute the vertical velocity statistics for each 30-min time period over each range gate, more than $30 \%$ of the data needs to be available. The vertical velocity variance, corrected as in Barlow et al. (2015), is used as a measure for the turbulent mixing in the boundary layer and a simple threshold $\left(0.1 \mathrm{~m}^{2} \mathrm{~s}^{-2}\right)$ is used to determine the mixing-layer height (Barlow et al. 2015; Halios and Barlow 2018; Theeuwes et al. 2019). To calculate the sensitivity of the mixing height to the threshold $0.1 \mathrm{~m}^{2} \mathrm{~s}^{-2}$, the value was perturbed by $30 \%$. For each averaging period, 21 threshold values ranging from 0.069 to $0.129 \mathrm{~m}^{2} \mathrm{~s}^{-2}$ were used and the height where the velocity variance drops below each threshold is stored as a possible mixing height. The final mixing height is the median of the 21 possible mixing heights. At the London site a reduction of signal intensity at the capping inversion limited the vertical velocity variance calculations during the deep convective boundary layer during daytime. For those times, the mixing height is determined from the signal intensity. The average signal intensity over a 30 -min period was vertically smoothed with a 7-point moving average. The minimum gradient of the smoothed signal is determined to be the mixing height, where mixing heights from the vertical velocity variance profiles were missing. 


\subsection{Low-Level-Jet Detection and Characterization}

Low-level jets are identified using a slightly modified version of the Baas et al. (2009) algorithm. A LLJ is defined as a low-level wind-speed maximum $\left(>4 \mathrm{~m} \mathrm{~s}^{-1}\right.$; below 650 $\mathrm{m}$ ) of at least $1.5 \mathrm{~m} \mathrm{~s}^{-1}$ (or $15 \%$ ) more than the wind speed in any of the overlying vertical levels (up to a height of 900 m). Previous studies (Baas et al. 2009; Kalverla et al. 2017) used a slightly modified minimum fall-off speed threshold $\left(2 \mathrm{~m} \mathrm{~s}^{-1}\right)$. However, Kalverla et al. (2019b) showed that the $2 \mathrm{~m} \mathrm{~s}^{-1}$ fall-off speed threshold might erroneously exclude LLJs occurring higher than $400 \mathrm{~m}$ a.g.l.

The LLJ characteristics identified here are: a) the occurrence frequency, b) the peak-jet speed $\left.\left(U_{L L J}\right), \mathrm{c}\right)$ the LLJ height $\left(z_{L L J}\right)$ a.g.l., and d) the fall-off speed $\left(F_{L L J}\right)$. Here, fall-off speed is defined as the difference between the peak wind speed at $z_{L L J}$ and the minimum wind speed between $z_{L L J}$ and $900 \mathrm{~m}$. Model and Doppler lidar data are interpolated to the same vertical levels using a simple linear interpolation before the LLJ detection algorithm is applied. The vertical levels start at $25 \mathrm{~m}$ a.g.l. (100 $\mathrm{m}$ a.g.l. for the lidar data) with a vertical spacing of $25 \mathrm{~m}$ until $600 \mathrm{~m}$ and a $50-\mathrm{m}$ resolution until $900 \mathrm{~m}$. Models and observations have a high vertical spacing near the surface and thus differences between linear and more complex polynomial (i.e., cubic) interpolation are small $\left(<0.1 \mathrm{~m} \mathrm{~s}^{-1}\right)$.

\section{Low-Level-Jet Characteristics for London and Chilbolton}

Low-level jets over London and Chilbolton are observed during both nights (Fig. 3e, f). Low aerosol concentrations gave an insufficient SNR during the first night and prevented windspeed measurements above $450 \mathrm{~m}$ a.g.l. Nevertheless, LLJs are identified in the Doppler lidar observations from 0000 UTC 15 May 2019 over the urban site and 2200 UTC 14 May 2019 over the rural site. The LLJs last until 0700 UTC 15 May 2019 over both sites. During the second night the LLJs are identified at 0000 UTC 16 May 2019 over both sites and last for $7 \mathrm{~h}$.

At 0000 UTC 15 May 2019 the LLJ height $\left(z_{L L J}\right)$ was higher over London $(450 \mathrm{~m})$ than Chilbolton $(300 \mathrm{~m})$, while the value of $U_{L L J}$ was lower $\left(10.0 \mathrm{~m} \mathrm{~s}^{-1}\right.$ versus $\left.11.5 \mathrm{~m} \mathrm{~s}^{-1}\right)$ (Fig. 3c, f). During the night, the value of $z_{L L J}$ decreases (Fig. 3e, f) over both sites. The decrease of the boundary-layer height coincides with the decrease in $z_{L L J}$ over London. Over Chilbolton the boundary-layer height (Fig. 3f) is located below the detection level (125 m a.g.l) of the Doppler lidar. During the second night the observed descent is smaller (50-100 m) (Fig. 3e). The LLJ descent during the night is likely to be caused by the decrease in the nocturnal boundary-layer depth and vertical mixing (inferred from the observed vertical variance profiles) (Fig. 3f). A similar relation between the value of $z_{L L J}$ and the minimum in the TKE vertical profile is reported over London and Chilbolton during the first night in the WRF model.

The jet speed $\left(U_{L L J}\right)$ decreases by $2-3 \mathrm{~m} \mathrm{~s}^{-1}$ for the urban site $\left(4-5 \mathrm{~m} \mathrm{~s}^{-1}\right.$ for the rural one) during the first night (Fig. 3e, f), but this should be handled with care due to limited data above $450 \mathrm{~m}$ a.g.l. No clear decrease in $U_{L L J}$ is observed during the second night (Fig. 3e, f). The evolution of the value of $U_{L L J}$ over London could be affected by both the baroclinicity over the North Sea (Online Resources 2, 3), evident from the variation of geostrophic wind speed with height over London (Online Resource 9), and by large-scale momentum advection (Online Resource 10). Both effects lead to a maximum $U_{L L J}$ at 0000 UTC 15 May 2019, which immediately starts to decrease. On the contrary, during the second night, baroclinicity 
(a)
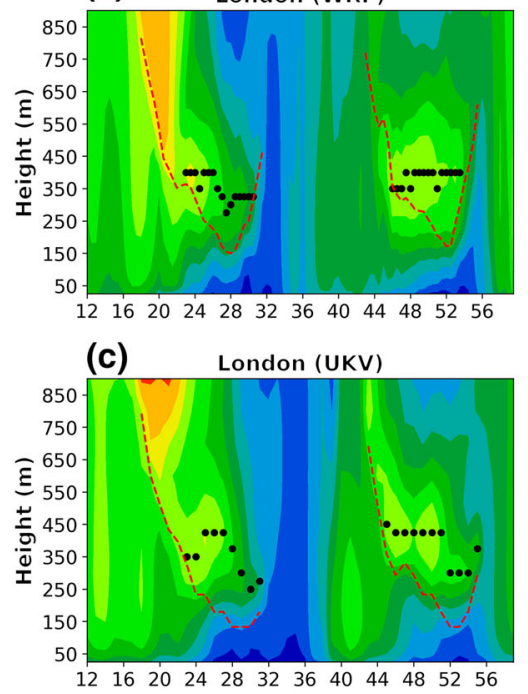

(e)

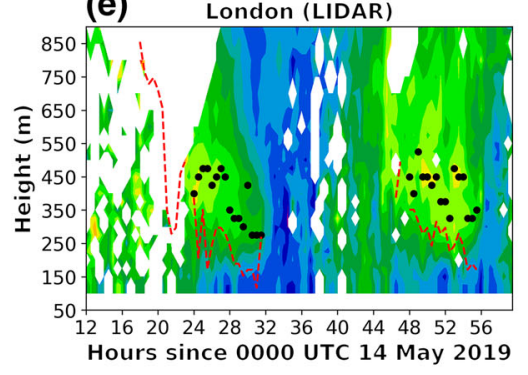

(b) Chilbolton (WRF)

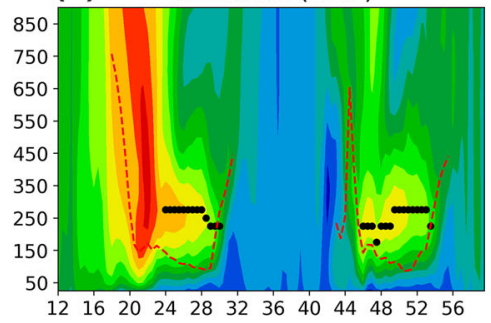

(d)

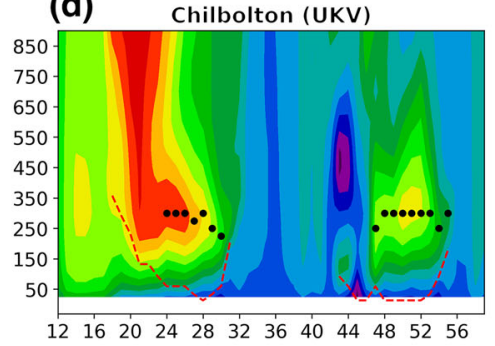

(f)

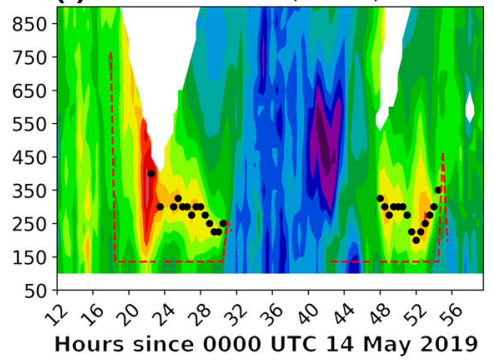

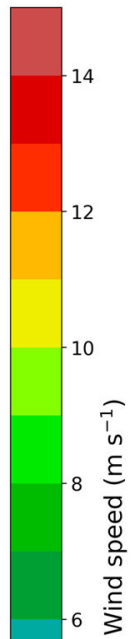

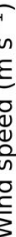

Fig. 3 Modelled (WRF,UKV) and observed (lidar) wind speed $\left(\mathrm{m} \mathrm{s}^{-1}\right)$ profile evolution over time for the two locations London (LSU) (a, c, e) and Chilbolton (b, d, f) for the period 1200 UTC 14 May 2019 to 1200 UTC 16 May 2019. Lidar measurements with large wind speed errors $\left(>1 \mathrm{~m} \mathrm{~s}^{-1}\right)$ are masked (white). Doppler lidar wind speeds are 30-min averages, while WRF and UKV use 30-min and 1-h instantaneous values respectively. Modelled and observed boundary-layer height (red line) and $z_{L L J}$ (black dots) are shown

is weaker and the LLJ exhibits an intensification phase more closely associated with an inertial oscillation, with wind speeds gradually increasing after sunset due to the difference between the actual and the geostrophic wind speeds (Online Resource 8). This oscillation is evident in the WRF results, through the increase in the $u$ wind component from $7 \mathrm{~m} \mathrm{~s}^{-1}$ to $10 \mathrm{~m} \mathrm{~s}^{-1}$ between 1900 UTC and 2400 UTC (Online Resource 8b, d), but it is not easily identified from the Doppler lidar due to larger variability in the measured wind speed. For more detailed wind speed and turbulence profiles see the supplementary material (Online Resources 4-7).

\section{Model Evaluation}

Here we evaluate the modelled LLJ characteristics $\left(F_{L L J}, U_{L L J}\right.$ and $\left.z_{L L J}\right)$ against observations on both sites. A general evaluation of the modelled (WRF) 2-m temperature, urban heat 
Table 2 Bias (root-mean-square error) for the modelled (WRF and UKV) $U_{L L J}\left(\mathrm{~m} \mathrm{~s}^{-1}\right), z_{L L J}(\mathrm{~m})$, and $F_{L L J}\left(\mathrm{~m} \mathrm{~s}^{-1}\right)$

\begin{tabular}{llllll}
\hline Site & London & & \multicolumn{3}{l}{ Chilbolton } \\
\cline { 2 - 3 } \cline { 5 - 6 } Model & WRF & UKV & & WRF & UKV \\
\hline$z_{L L J}(\mathrm{~m})$ & $-46.4(77.7)$ & $-53.1(83.8)$ & & $-16.9(41.5)$ & $4.7(37.2)$ \\
$U_{L L J}\left(\mathrm{~m} \mathrm{~s}^{-1}\right)$ & $-0.82(0.95)$ & $-0.93(1.15)$ & & $-0.66(1.14)$ & $-0.59(1.58)$ \\
$F_{L L J}\left(\mathrm{~m} \mathrm{~s}^{-1}\right)$ & $0.75(1.15)$ & $0.05(1.78)$ & & $-0.23(1.69)$ & $-0.75(2.00)$ \\
\hline
\end{tabular}

The comparison is based on the in situ Doppler lidars at London (LSU) and Chilbolton. Statistical scores are an average of $13 \mathrm{~h}$ (UKV) and 26 30-min (WRF) bias estimations over London (17 and 25 over Chilbolton, respectively) during both nights, calculated only at times when an LLJ is detected in both the Doppler lidar and the modelled wind profiles

island intensity, and 10-m wind speed with respect to in situ observations is also provided as supplementary information (Online Resources 1, 11-13). A comparison of modelled and observed nocturnal vertical wind-speed profiles for London and Chilbolton is also provided in supplementary material (Online Resources 14, 15).

The WRF and UKV models are able to reproduce the LLJs during the case study period (Fig. 3 and Table 2). The formation and dissipation timing of the LLJ is similar during the first night for both models and lidar observations (Fig. 3), but during the second night the LLJ is formed $3 \mathrm{~h}$ earlier in both models and dissipates $1 \mathrm{~h}$ earlier than observed (Fig. 3). Both models capture the decrease in the value of $z_{L L J}$ over London and Chilbolton during the first night. However, during the second night the value of $z_{L L J}$ remains rather constant according to the WRF model, while the UKV model is still able to capture the decrease in the value of $z_{L L J}$ over London.

The value of $z_{L L J}$ is underestimated over London $(-46.2 \mathrm{~m}$ in WRF and $-53.1 \mathrm{~m}$ in UKV) (Table 2). Both models underestimate $z_{L L J}$, particularly between 0000-0400 UTC (Fig. 3a, c, e). The temporal change in $z_{L L J}$ bias matches the difference between the modelled and observed UBL height (Fig. 4). The earlier dissipation of the urban LLJs in the WRF results might be linked to the more rapid increases in UBL height (and thus vertical mixing) during the early morning hours (Fig. 4). The delay in the collapse of the observed UBL is also supported by the observed kinematic heat flux between 2000-0000 UTC during both nights (Online Resource 16) measured at the British Telecom tower [175 m a.g.l, site details at Wood et al. (2010)]. The bias in modelled $z_{L L J}$ over Chilbolton is substantially lower $(-16.9 \mathrm{~m}$ in WRF and $4.7 \mathrm{~m}$ in UKV) than over London.

Although the WRF and UKV models successfully capture the value of $U_{L L J}$ over London at midnight (Fig. 3), both models tend to dissipate the LLJ faster than observed leading to an increasing underestimation of $U_{L L J}$ over the course of the night. The earlier collapse of the modelled UBL during the first night may explain the earlier $(3 \mathrm{~h}) \mathrm{LLJ}$ formation in both models. This could result in a lag between the modelled and observed evolution of the LLJ, with modelled inertial oscillations starting earlier than observed. Consequently, the LLJ in the WRF and UKV models reaches maximum speeds a few hours earlier than in the observations, also leading to a faster dissipation of the LLJ. This would explain the lower modelled $U_{L L J}$ between 0300-0700 UTC (Fig. 3a, c). Overall, the mean $U_{L L J}$ bias for the WRF and UKV models over both nights is -0.82 and $-0.93 \mathrm{~m} \mathrm{~s}^{-1}$, respectively (Table 2). Over Chilbolton, the $U_{L L J}$ mean bias is slightly larger in the WRF model $\left(-0.66 \mathrm{~m} \mathrm{~s}^{-1}\right)$ than in the UKV model $\left(-0.59 \mathrm{~m} \mathrm{~s}^{-1}\right)$. 


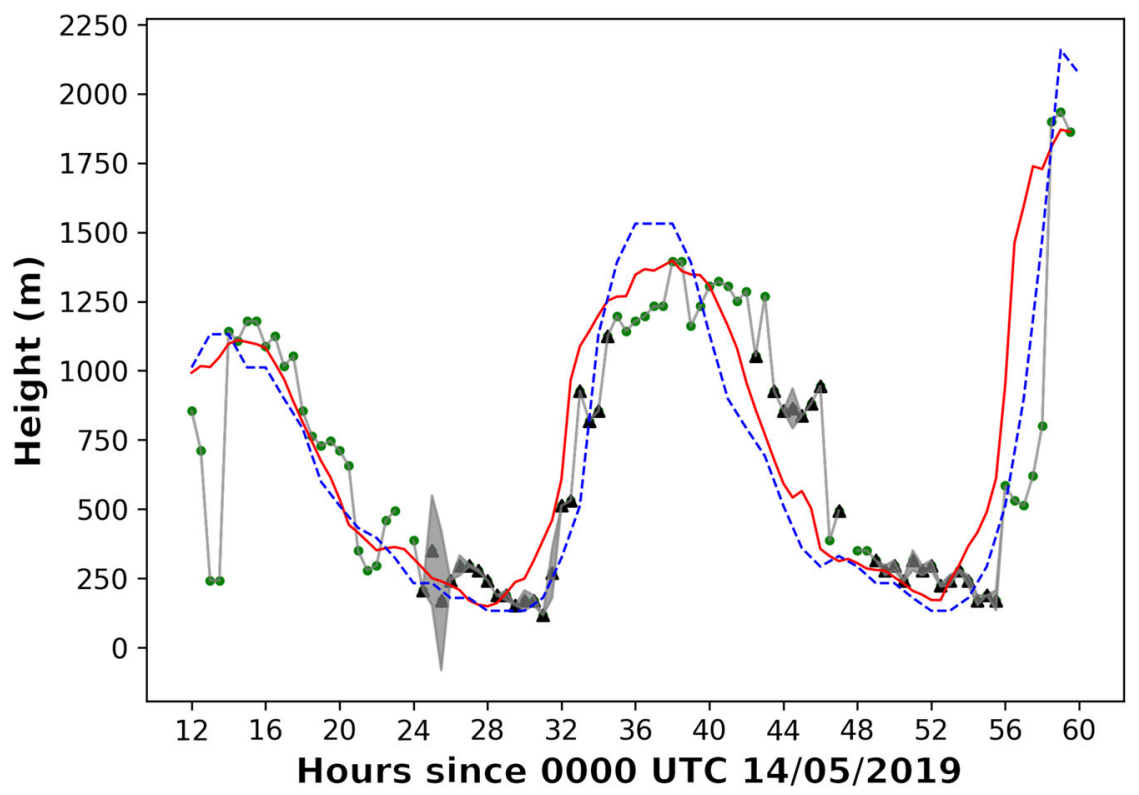

WRF ---- UKV $\boldsymbol{\Delta}$ LIDAR vertical variance

LIDAR signal gradient

Fig. 4 Boundary-layer height (m) over London estimated from WRF (red), UKV (blue) and the Doppler lidar (black triangles) 50th percentile of the vertical variance method (green dots) for the period 1200 UTC 14 May 2019 to 1200 UTC 16 May 2019. The shaded gray area indicates uncertainty range (75th-25th percentile) from the lidar-derived boundary-layer height when the vertical velocity variance profiles are used. Detailed information on the lidar-derived boundary-layer height is provided in Sect. 2.4

The fall-off speed $\left(F_{L L J}\right)$ is overestimated over London $\left(0.75 \mathrm{~m} \mathrm{~s}^{-1}\right.$ in WRF versus 0.05 $\mathrm{m} \mathrm{s}^{-1}$ in UKV), but underestimated over Chilbolton $\left(-0.23 \mathrm{~m} \mathrm{~s}^{-1}\right.$ in WRF and -0.70 $\mathrm{m} \mathrm{s}^{-1}$ in UKV) during both nights. During the second night, the positive bias in $F_{L L J}$ over the urban site mainly originates from a strong negative bias in upper residual-layer wind speed (Fig. 3a, b). The WRF model also shows a negative bias during the first night, which is caused by the advection of a low-momentum air mass between 700-900 $\mathrm{m}$ around 2100 UTC (Online Resource 10a). Over Chilbolton the underestimation in $F_{L L J}$ is partially caused by a positive bias in the 700-900 $\mathrm{m}$ wind speed in both models during the first night. Considering the observational uncertainty in measure wind speed $\left(0.5 \mathrm{~m} \mathrm{~s}^{-1}\right)$ it is difficult to conclude whether one of the two models is better at capturing the LLJ.

\section{Differences in Low-Level-Jet Characteristics Between London and Chilbolton}

In this section we analyze the differences in the LLJ characteristics between London and Chilbolton for two periods: (a) 1900 UTC 14 May 2019 to 1000 UTC 15 May 2019 and (b) 1900 UTC 15 May 2019 to 1000 UTC 16 May 2019. We apply the LLJ detection algorithm (Sect. 2.5) to the wind speed obtained from the WRF and UKV models and the Doppler lidar (Fig. 5). For the WRF and UKV models, the LLJ characteristics are averaged over all urban grid-cells of London within a $75 \times 60 \mathrm{~km}^{2}$ area, for which an LLJ is detected. The LLJ 

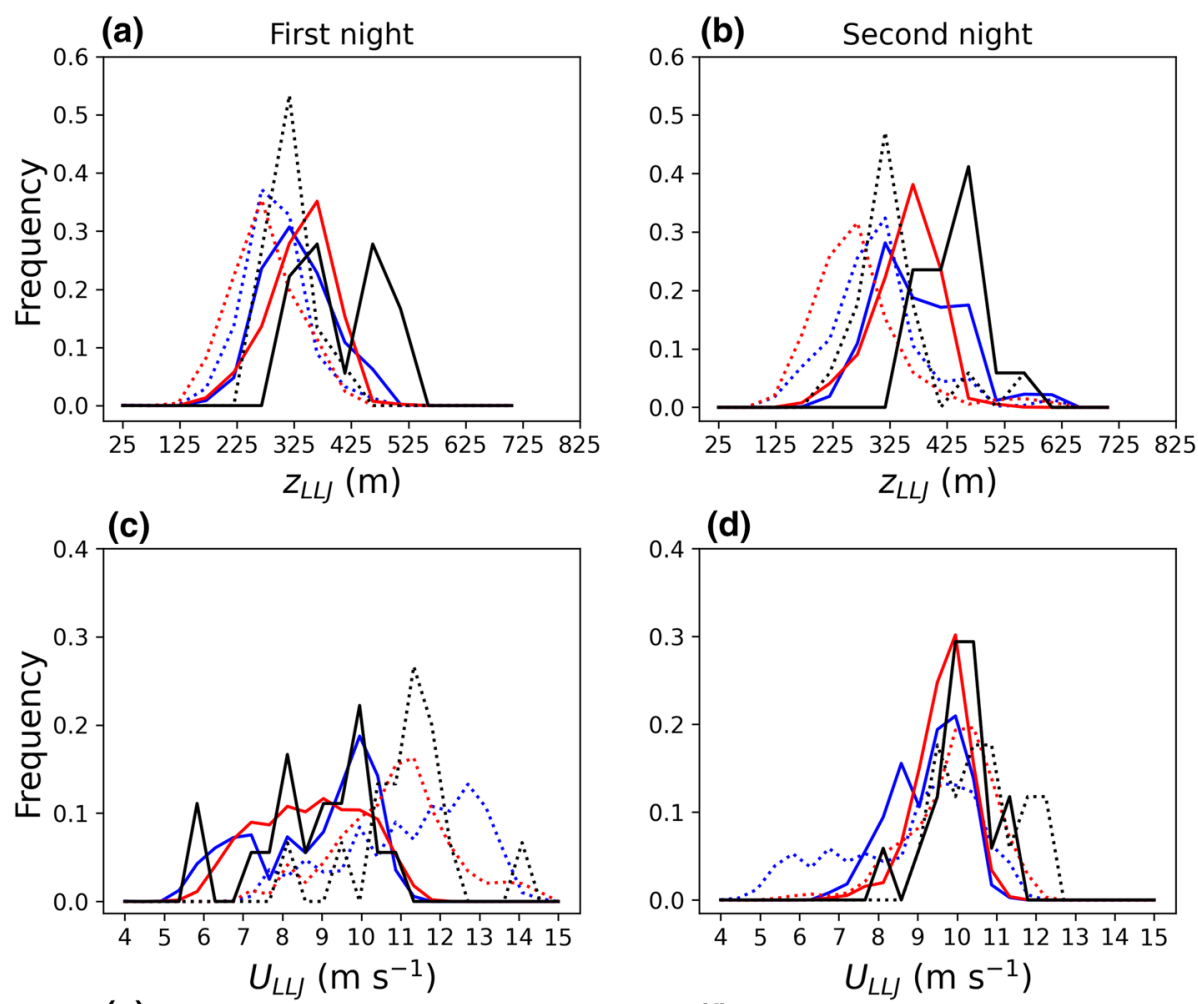

(d)
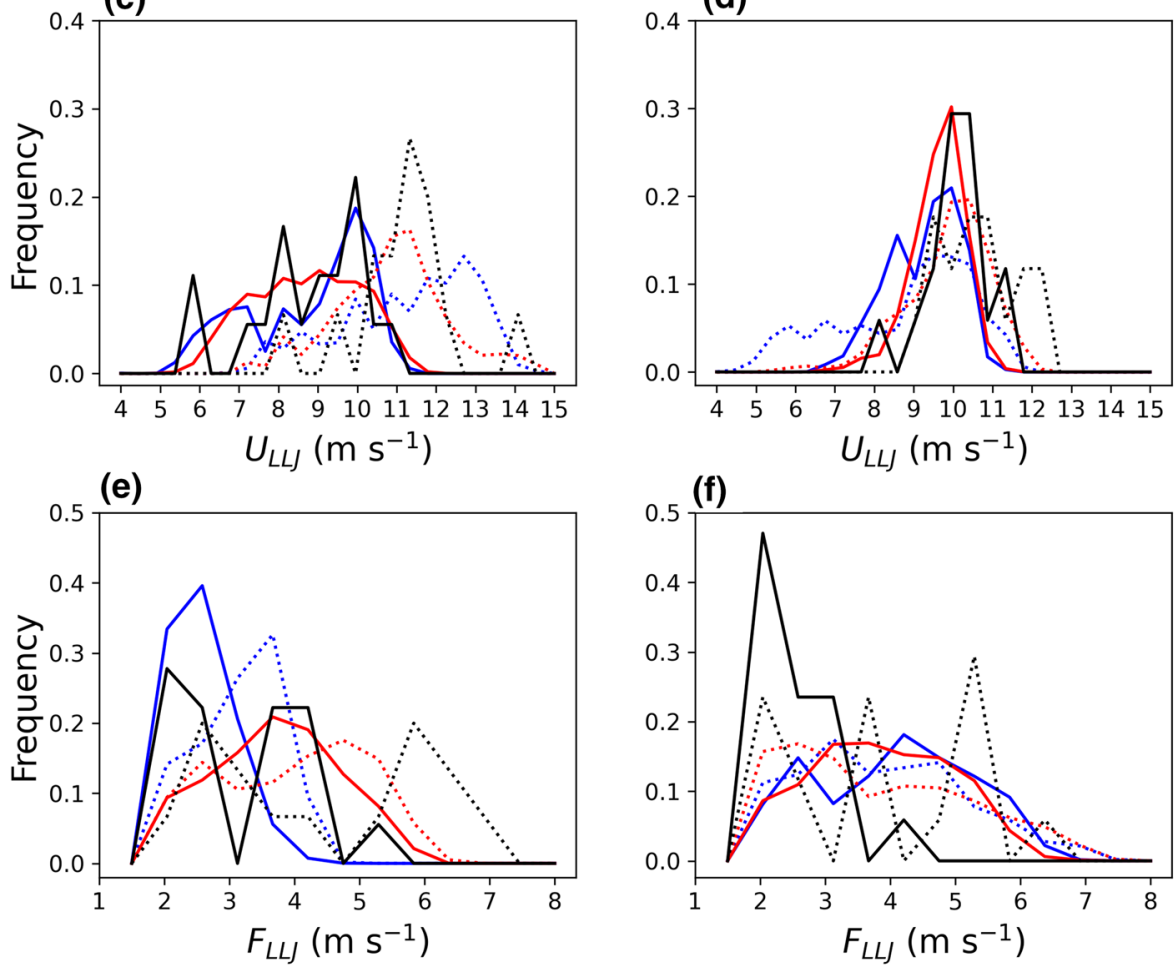

\begin{tabular}{llllll|} 
& London_UKV & & London_WRF & - & London_LIDAR \\
$\cdots \cdots$ & Chilbolton_UKV & $\cdots \cdots$ & Chilbolton_WRF & $\cdots \cdots$ & Chilbolton_LIDAR \\
\hline
\end{tabular}

Fig. 5 Modelled (red for WRF, blue for UKV) and observed (black) frequency distribution of the $z_{L L J}$ (a, b), $U_{L L J}(\mathbf{c}, \mathbf{d})$ and $F_{L L J}(\mathbf{e}, \mathbf{f})$ for London (solid lines) and Chilbolton (dotted lines) during the first (1900 UTC 14 May 2019 to 1000 UTC 15 May 2019) and second period (1900 UTC 15 May 2019 to 1000 UTC 16 May 2019) 
Table 3 Mean values (standard deviation) for $U_{L L J}\left(\mathrm{~m} \mathrm{~s}^{-1}\right), z_{L L J}(\mathrm{~m})$, and $F_{L L J}\left(\mathrm{~m} \mathrm{~s}^{-1}\right)$ over London and Chilbolton, from the Doppler lidar and the WRF and UKV models for the first (1900 UTC 14 May 2019-1000 UTC 15 May 2019) and second (1900 UTC 15 May 2019-1000 UTC 16 May 2019) nights

\begin{tabular}{|c|c|c|c|c|c|c|}
\hline \multirow[t]{2}{*}{ Site } & \multicolumn{3}{|l|}{ London } & \multicolumn{3}{|l|}{ Chilbolton } \\
\hline & WRF & UKV & Doppler lidar & WRF & UKV & Doppler lidar \\
\hline \multicolumn{7}{|c|}{ (a) First night } \\
\hline$z_{L L J}$ & $305(64)$ & $306(63)$ & 377 (74) & $235(61)$ & $262(58)$ & $291(44)$ \\
\hline$U_{L L J}$ & $8.5(1.4)$ & $8.5(1.5)$ & $8.5(1.4)$ & $10.7(1.4)$ & $11.1(1.7)$ & $10.8(1.2)$ \\
\hline$F_{L L J}$ & $3.4(1.0)$ & $2.3(0.5)$ & $2.9(1.0)$ & $3.6(1.1)$ & $2.9(0.7)$ & $4.1(1.6)$ \\
\hline \multicolumn{7}{|c|}{ (b) Second night } \\
\hline$z_{L L J}$ & $325(64)$ & 349 (79) & $411(56)$ & $232(86)$ & $273(86)$ & 307 (78) \\
\hline$U_{L L J}$ & $9.4(0.7)$ & $9.0(0.9)$ & $9.8(0.7)$ & $9.7(1.1)$ & $8.6(1.7)$ & $10.3(0.9)$ \\
\hline$F_{L L J}$ & $3.6(1.1)$ & $3.8(1.2)$ & $2.3(0.6)$ & $3.5(1.4)$ & $3.6(1.3)$ & $3.6(1.4)$ \\
\hline
\end{tabular}

The observed mean values and standard deviations are based on 35 30-min profiles over London (17 for the first night and 18 for the second night) and 32 over Chilbolton (15 for the first night and 17 for the second night)

characteristics over Chilbolton are quantified over an area of $45 \times 45 \mathrm{~km}^{2}$. This ensures that the modelled LLJ characteristics are not based on profiles from only one urban and one rural point. The observed occurrence frequency of the LLJs is very similar for both London (34\%) and Chilbolton (32\%). A non-parametric Mann-Whitney test is also conducted to evaluate the statistical significance of the differences in LLJ characteristics between the two sites. The modelled data have the potential to be spatially auto-correlated (i.e., reduced effective sample size) and thus we used a randomly selected sample of 5\% from all the quantified model data for the Mann-Whitney test. The test is iterated 100 times to yield robust statistical significance scores.

The observed values of $z_{L L J}$ are higher over London for both nights $\left(\Delta z_{L L J}=85 \mathrm{~m}\right.$ and $104 \mathrm{~m}$, respectively) compared to Chilbolton, with a shift of the $z_{L L J}$ distribution towards higher $z_{L L J}$ values (Fig. 5a, b and Table 3). In the UKV model, $z_{L L J}$ is higher over London by $44 \mathrm{~m}$ (first night) and $75 \mathrm{~m}$ (second night), while in the WRF model the $z_{L L J}$ differences between London and Chilbolton are $70 \mathrm{~m}$ and $92 \mathrm{~m}$, respectively. These differences are statistically significant $(p<0.05)$ for the WRF and UKV models, and the Doppler lidar observations. However, significance tests for the Doppler lidar should be handled with care due to the uncertainty of the measured wind speed and the low number of measured vertical LLJ profiles. The $z_{L L J}$ differences can be partially attributed to the stronger turbulent mixing and deeper boundary layer over London compared to Chilbolton (see Sect. 7).

During the first night, the observed value of $U_{L L J}$ is higher over Chilbolton $\left(10.8 \mathrm{~m} \mathrm{~s}^{-1}\right)$ with the frequency distribution shifted towards higher $U_{L L J}$ values compared to London (8.5 $\mathrm{m} \mathrm{s}^{-1}, p<0.05$ ) (Fig. 5c, $\mathrm{d}$ and Table 3). However, the second night $\Delta U_{L L J}$ is only 0.5 $\mathrm{m} \mathrm{s}^{-1}(p>0.05)$. The lack of consistent $\Delta U_{L L J}$ between the two sides indicates that the value of $U_{L L J}$ is also affected by non-urban effects, such as the difference in the geostrophic wind speed, the large-scale momentum advection, and topography around the two sites. Both the WRF and UKV models show similar statistical significant differences $(p<0.01)$ in $U_{L L J}$ between the two sites as the Doppler lidar observations (Table 3), but the UKV model maintains a slightly higher $U_{L L J}$ value over London during the second night.

The average observed $F_{L L J}$ difference between London and Chilbolton amounts to $\Delta F_{L L J}=-1.2 \mathrm{~m} \mathrm{~s}^{-1}$ and $-1.3 \mathrm{~m} \mathrm{~s}^{-1}$ during both nights (Fig. 5e, $\mathrm{f}$ and Table 3). 
The bimodal distribution over London (first night) and Chilbolton (both nights) is likely to be caused by the lack of observed wind speeds above $500 \mathrm{~m}$. The difference in the $F_{L L J}$ distributions between the UKV and WRF models during the first night is attributed to an underestimation of the wind speed between 700-900 $\mathrm{m}$ in the WRF model (Figs. 3a, c, and 5e). This highlights the sensitivity of $F_{L L J}$ to momentum advection and the accurate representation of the geostrophic wind speed.

\section{Spatial Distribution of Low-Level-Jet Characteristics over London}

This analysis is conducted in a $75 \times 60 \mathrm{~km}^{2}$ area centred around London, so it excludes the rural site of Chilbolton. The predominant wind direction at $850 \mathrm{hPa}$ is easterly during both nights, but can vary slightly from east-north-east to east-south-east during the night.

The value of $z_{L L J}$ is higher over the urban grid-cells and the rural areas downwind of London, compared to the countryside north and south of London (Figs. 6c, d, and 7a, b). The $z_{L L J}$ difference between urban and rural grid-cells, is $50 \mathrm{~m}$ in the WRF results and $47 \mathrm{~m}$ in UKV results during both nights. Part of this difference can be attributed to the increased values of TKE over London (discussed later in Sect. 8). The higher turbulent mixing over London increases the height at which turbulent drag affects the flow, resulting in an increase of $z_{L L J}$. Analogous mechanisms between boundary-layer height and $z_{L L J}$ were also reported by Pichugina and Banta (2010) and Klein et al. (2016). The urban plume transports air with high TKE downwind of the urban area leading to elevated values of $z_{L L J}$ over the downwind rural areas in both models (Fig. 6a, b, and Sect. 7). Overall, the modelled $z_{L L J}$ is positively correlated with the modelled boundary-layer depth $(r \approx 0.80, p<0.001$ Online Resource $17 \mathrm{a}, \mathrm{b})$. Terrain height appears to be anti-correlated with $z_{L L J}(r=-0.82, p<0.001$ for the first night; $r=-0.68, p<0.001$ for the second night, Online Resources $17 \mathrm{c}, \mathrm{d})$. The impact of topography is also evident in the elevated $z_{L L J}$ values upwind of London. Here, blocking effects from topographic features near the coast (Fig. 2c) result in an area of convergence (51.5N, 0.75E in Online Resource 19) between the North Sea and the Thames estuary (see Fig. 2c). The elevated LLJ flow from that area is channelled through the Thames valley into London (see Sect. 7.2).

The difference in $U_{L L J}$ between London and the rural surroundings is small for the first night $\left(\triangle U_{L L J}=0.27 \mathrm{~m} \mathrm{~s}^{-1}\right.$ in the UKV model, $0.15 \mathrm{~m} \mathrm{~s}^{-1}$ in the WRF model) and negligible the second night $\left(<0.05 \mathrm{~m} \mathrm{~s}^{-1}\right)$. A decrease in the value of $U_{L L J}$ downwind of the city (westnorth-west) is visible the second night (Fig. 7e, f). The increase of the value of $U_{L L J}$ towards the south (first night) is associated with larger geostrophic wind speed and baroclinicity south of London.

The spatial variability of $F_{L L J}$ (Fig. 6a, b) can be partially explained by the changes in the spatial distribution of the $U_{L L J}$ values over the domain. However, the spatial variability in $F_{L L J}$ is also affected by the changes in the geostrophic wind speed and momentum advection above the height of the LLJ. The relation between the spatial variability in values of $z_{L L J}$, $U_{L L J}$ and $F_{L L J}$ is further discussed in Sects. 7 and 9. Vertical distributions of geostrophic wind and momentum advection over London, along with vertical velocity spatial distribution, are available in the supplementary material (Online Resources 9, 10, and 18). 

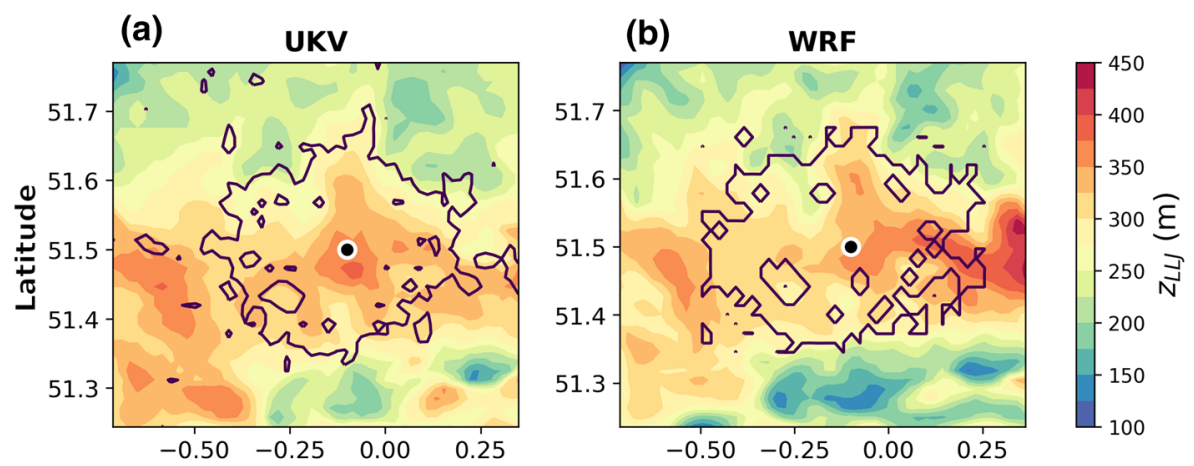

(c)

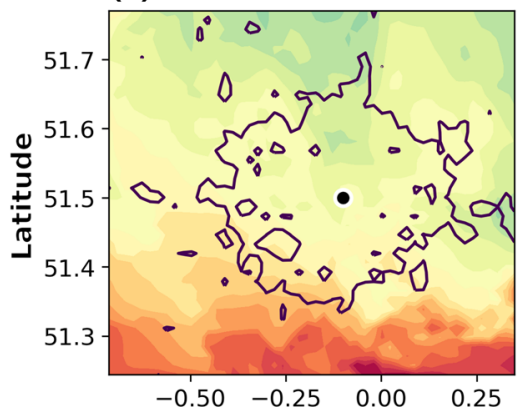

(d)

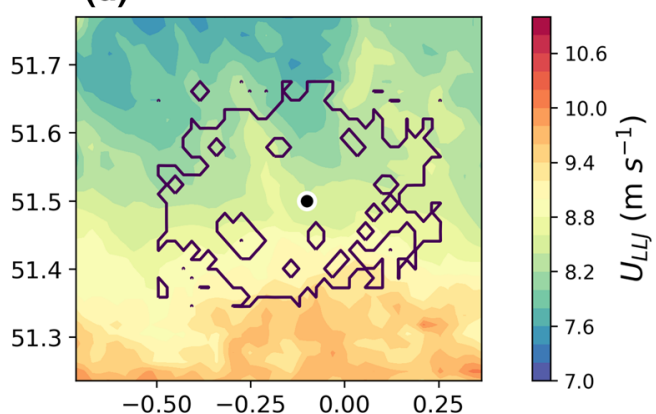

(e)

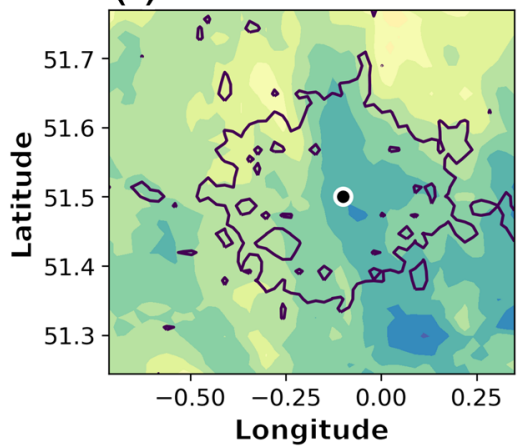

(f)

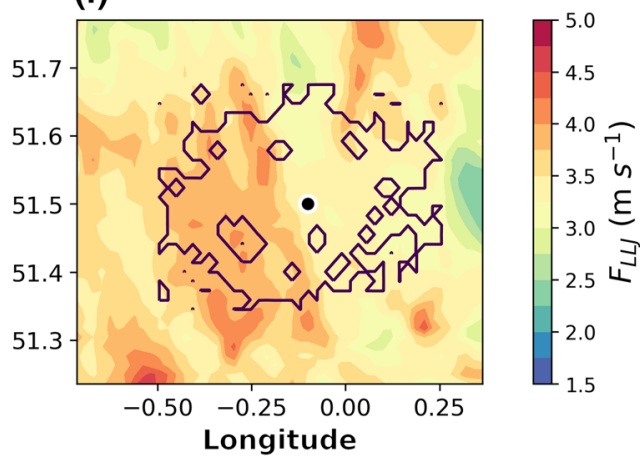

Fig. 6 Spatial distribution of the time-averaged $z_{L L J}(\mathbf{a}, \mathbf{b}), U_{L L J}(\mathbf{c}, \mathbf{d})$ and $F_{L L J}(\mathbf{e}, \mathbf{f})$ within and around London in the UKV (a, c, e) and the WRF (b, d, f) models, during the first night (2200 UTC 14 May 20190600 UTC 15 May 2019). The boundary of London's urban area is defined (black line) for both WRF (land use grid-cell index is urban) and UKV domains (urban fraction > 0.4). The location of the Doppler lidar is depicted with the black and white dot

\section{Isolating Urban and Non-urban Effects on the Low-Level-Jet Characteristics}

In this section, we discuss results from two WRF sensitivity experiments to isolate the influence of urban and topographic effects on the difference in the LLJ characteristics between the two sites. The experiments include: (a) the replacement of the urban LUCs of London with the dominant surrounding vegetation (cropland experiment) and (b) reduction of topo- 

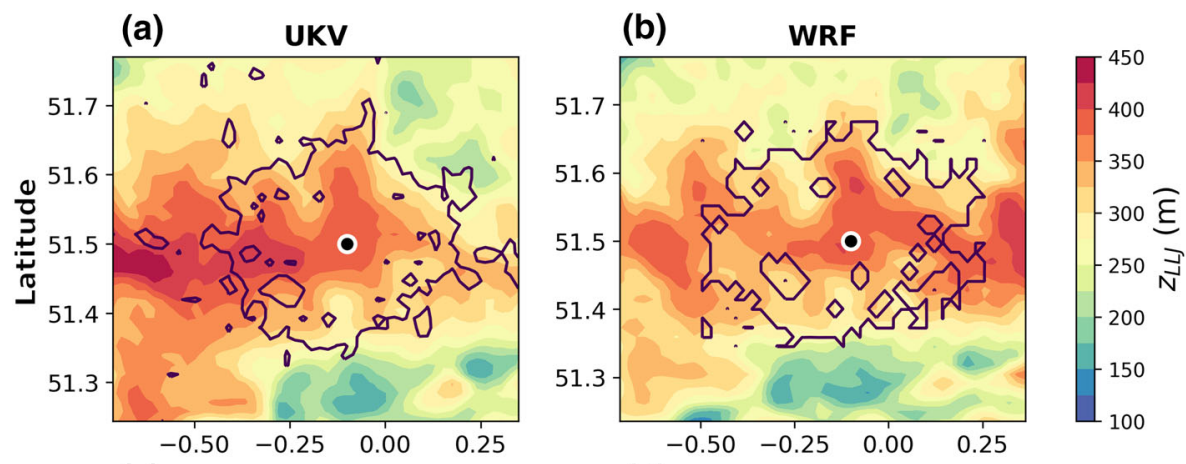

(c)

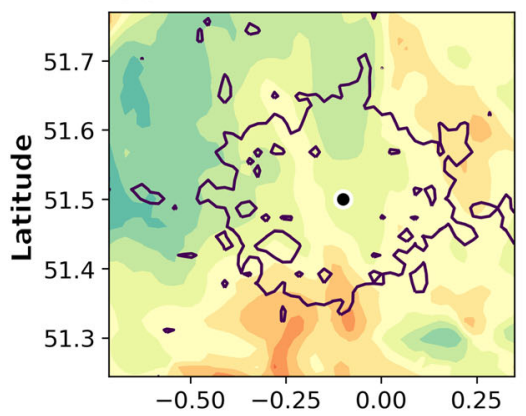

(d)

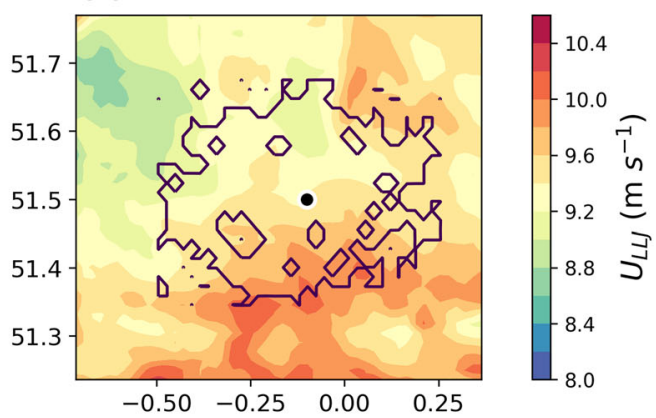

(e)

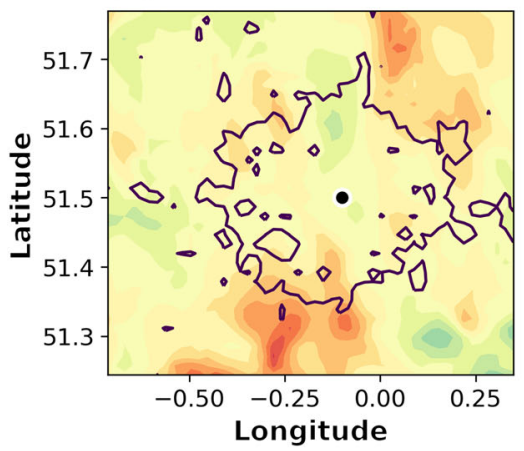

(f)

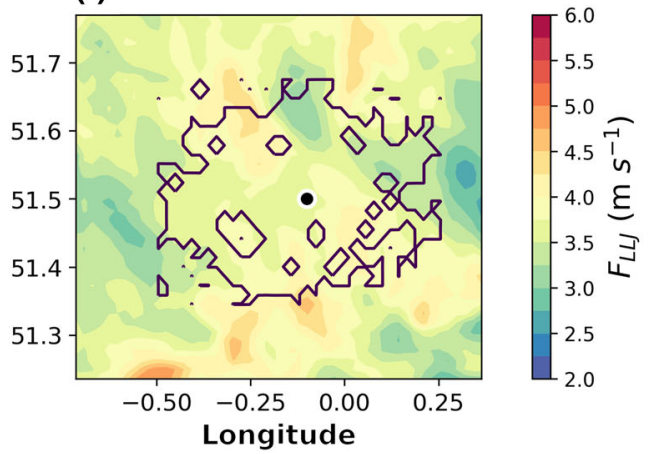

Fig. 7 As Fig. 6, but for the second night (2100 UTC 15 May 2019 to 0600 UTC 16 May 2019)

graphic height to $0 \mathrm{~m}$ in the inner domain (no-topography, hereinafter 'notopo' experiment). As in Sect. 5, the differences are calculated for all grid-cells in the $75 \times 60 \mathrm{~km}^{2}$ area around London. Frequency distribution plots for LLJ characteristics over London in the reference, cropland and notopo experiments are also provided in the supplementary material (Online Resource 19). 


\subsection{Urban Effects on the Low-Level-Jet Characteristics over London}

The LLJ characteristics over Chilbolton are nearly identical in the cropland and reference experiments $\left(<3 \mathrm{~m}\right.$ difference in $z_{L L J}$ and $<0.1 \mathrm{~m}$ difference in $\left.U_{L L J}\right)$ and are thus not discussed.

Over the urban area of London the cropland run shows a statistically significant decrease ( $p$ $<0.001$ ) of around $37 \mathrm{~m}$ in $z_{L L J}$ during both nights compared to the reference experiments, with a distribution shifting to lower $z_{L L J}$. Differences in the value of $z_{L L J}$ between the cropland and reference experiments are located mainly over the urban area and the rural areas downwind (west), and can exceed $80 \mathrm{~m}$ in some locations (Fig. 8a, b). These difference can be attributed to the stronger turbulent mixing over London in the reference experiment.

The jet speed $\left(U_{L L J}\right)$ over the urban area of London is slightly shifted toward higher values $\left(0.26 \mathrm{~m} \mathrm{~s}^{-1}, p<0.01\right)$ in the cropland experiment compared to the reference (Fig. $8 \mathrm{e}, \mathrm{f})$. A slight increase in the values $F_{L L J}\left(0.2 \mathrm{~m} \mathrm{~s}^{-1}\right)$ is seen in the cropland run, which is likely to be caused by the increase in $U_{L L J}$ (see Sect. 6). We find increased values of $U_{L L J}$ up to more than $20 \mathrm{~km}$ downwind (west-north-west) of London (Fig. 8c, e), which matches the finding of Lemonsu et al. (2009) on the impact of Oklahoma City on $U_{L L J}$ downwind of the urban area.

In the cropland experiment, the LLJ is detected an hour earlier over London and approximately $15 \mathrm{~km}$ further downwind by 2300 UTC compared to the reference experiment during both nights. This indicates that the turbulent mixing still present in the nocturnal UBL during the evening (1800-2200 UTC) delays the decoupling of the flow and the inland propagation of the LLJ. The faster LLJ onset in the cropland experiment and presence of strong momentum advection over London in the reference experiment indicate that the LLJ could have been formed earlier over the surrounding rural areas of London and then advected over the city as proposed by Barlow et al. (2015).

The differences in the values of $z_{L L J}$ over London between the cropland and the reference experiments $(37 \mathrm{~m})$ do not match the differences in the values of $z_{L L J}$ between London and Chilbolton $(75 \mathrm{~m})$. Based on this analysis, increased turbulent mixing over the urban area could be responsible for about $50 \%$ of the reported $z_{L L J}$ difference between the two sites (Sect. 5). The urban effect on the $U_{L L J}$ over London is small $\left(-0.26 \mathrm{~m} \mathrm{~s}^{-1}\right)$ compared to the difference reported between the two sites for the first night $\left(-2.1 \mathrm{~m} \mathrm{~s}^{-1}\right)$. Due to the nonlinear interactions between the urban surface, UBL dynamics, topography, and synoptic flow this attribution should be handled with care. Still our results indicate that the differences in LLJ characteristics between London and Chilbolton are not solely caused by urban effects.

\subsection{Topographic Effects on the Low-Level-Jet Characteristics over London}

In the notopo experiment the mean $z_{L L J}$ decreases over the urban area by $33 \mathrm{~m}$ compared to the reference experiment. The difference in the spatial distribution of the values of $z_{L L J}$ (Fig. 8d) cannot be explained solely by the changes in boundary-layer height between the two experiments, because the latter is substantially smaller than the changes in $z_{L L J}$ (Online Resource 20). Thus, it is necessary to discuss which orographic effects could explain the difference in $z_{L L J}$.

In the areas upwind (to the east) of London, the value of $z_{L L J}$ is lower in the notopo experiment compared to the reference, which may be caused by the lack of orographic blocking/drag effects in combination with gap flow along the Thames Valley (see Sect. 6). The positive vertical velocity component at $300 \mathrm{~m}$ a.g.l over the Thames Estuary $\left(51^{\circ} 30^{\prime} 00^{\prime \prime} \mathrm{N}\right.$; 
(a)

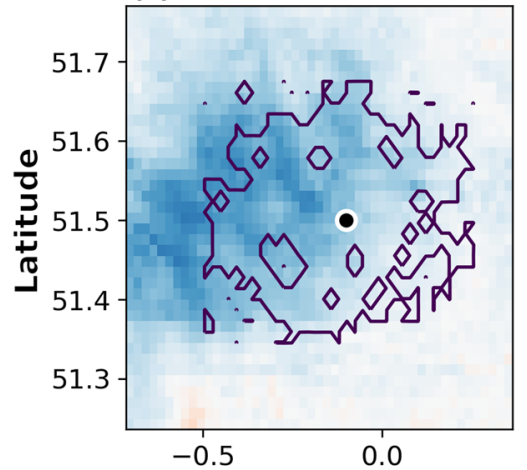

(c)

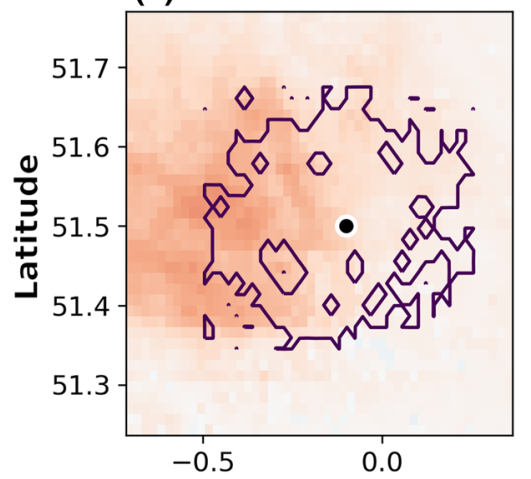

(e)

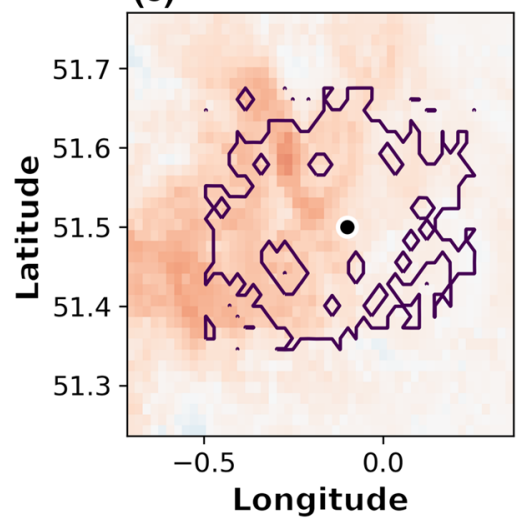

(b)

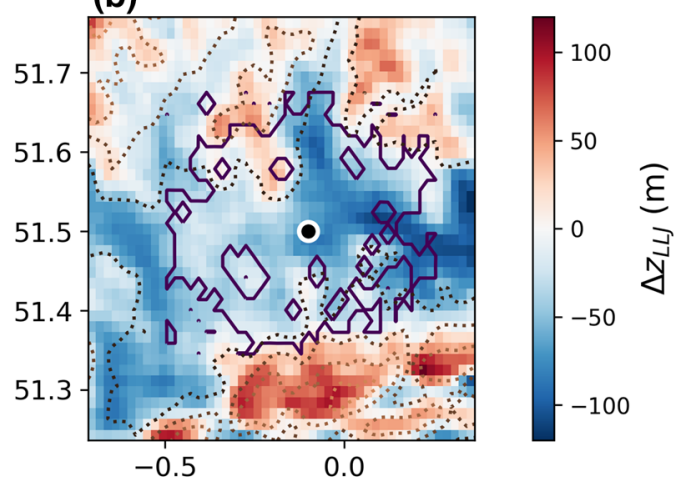

(d)

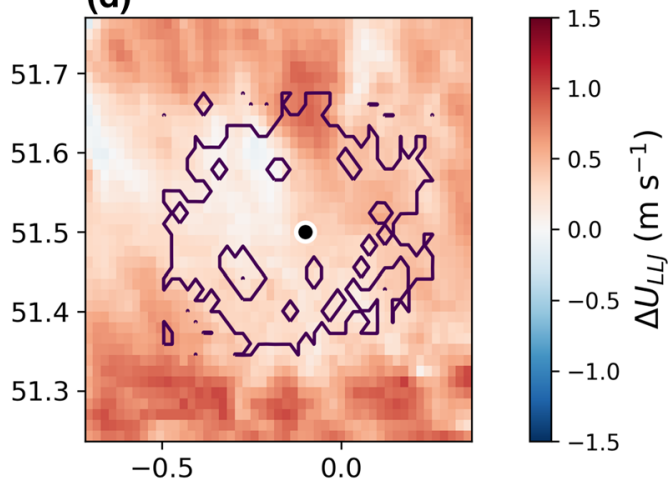

(f)

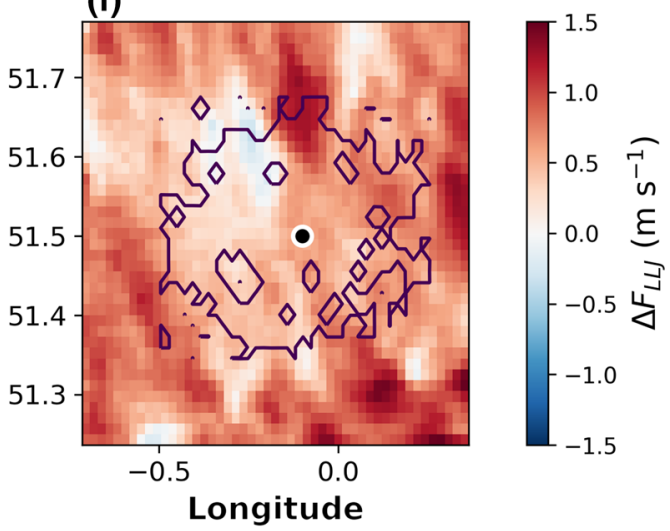

Fig. 8 Spatial distribution of the difference in modelled WRF $z_{L L J}(\mathbf{a}, \mathbf{b}), U_{L L J}(\mathbf{c}, \mathbf{d}), F_{L L J}(\mathbf{e}, \mathbf{f})$ over London between the reference and cropland (cropland - reference) (a, c, e) and the reference and notopo (notopo - reference) (b, d, f) WRF experiments averaged during the both nights (2100 UTC 14 May 20190600 UTC 15 May 2019 and 2100 UTC 15 May 2019-0600 UTC 16 May 2019). The boundaries of London's urban area are defined (black line) using the land-use index from the WRF model, while the location of the Doppler lidar is depicted with the black and white dot 
$0^{\circ} 45^{\prime} 00^{\prime \prime} \mathrm{E}$ in Online Resource 18) just ahead of the increase in terrain elevation, can enhance vertical momentum transport leading to elevated LLJs and increased values of $z_{L L J}$. In the areas north and south of London, the correlation between vertical velocity component and terrain height (Online Resource 18) hints to the presence of orographic gravity waves. These waves can affect the vertical transport of momentum leading to subsidence in the leeward side and convergence in the windward side of the topography. In addition, turbulence from breaking waves can influence the wind profile (as seen in Steeneveld et al. 2008; Lapworth et al. 2016) and thus the value of $z_{L L J}$.

The removal of topographic features also increases the modelled $U_{L L J}$ over London by 0.3 $\mathrm{m} \mathrm{s}^{-1}$ (Fig. 8f) compared to the reference experiment. A larger increase in the value of $U_{L L J}$ is visible south and north of London, which reinforces the hypothesis that the topography impacts the wind flow over these areas. The increase in $U_{L L J}$ in the notopo experiment also increases the value of $F_{L L J}$ (Fig. 8b, f). However, since $F_{L L J}$ increases more than $U_{L L J}$ in the notopo experiment (Fig. 8b, f), this indicates that the wind speed in the upper part of the residual layer also decreases. This is an effect of the lower geostrophic wind speed $(\approx 0.5$ $\mathrm{m} \mathrm{s}^{-1}$ ) in the notopo experiment.

From our previous analysis it is clear that topography has a substantial effect on the LLJ characteristics and their spatial distribution via orographic effects (i.e., flow blocking, gap flows, and orographic gravity waves) and potential changes in the surface energy balance. The topographic effect on LLJ characteristics is dominant upwind (east), south, and north of London, while over the city and downwind (west) the effects of urban and topography are comparable in magnitude.

\section{Low-Level-Jet Effects on the Turbulence Kinetic Energy in the Nocturnal Boundary Layer}

The temporal evolution of TKE (variable notation $e$ ) and its shear and buoyancy production terms within the nocturnal UBL offers insight into the turbulent mixing effects on the LLJ and the possible presence of an 'upside-down' UBL structure. Thus, we investigate the nocturnal production of TKE between $50 \mathrm{~m}$ and the boundary-layer top over London and the surrounding rural areas utilizing the reference and two idealized (cropland, notopo) experiments. We exclude the lowest level $(25 \mathrm{~m})$ as the urban roughness effects might be dominant there. Note that the shear and buoyancy production of TKE in the MYNN scheme are proportional to the mixing length and $\sqrt{e}$. Thus, differences in the production terms of TKE between the experiments are not only driven by changes in wind shear and buoyancy, but also by the value of $e$.

The value of $e$ is higher over London during the course of the night in the reference and notopo experiments compared with the cropland experiment (Fig. 9a, b). This supports the hypothesis that the stronger turbulent mixing over London increases the value of $z_{L L J}$ and slightly reduces in the value of $U_{L L J}$. Klein et al. (2016) also showed that an increase in the value of $z_{L L J}$ and a decrease in the value of $U_{L L J}$ for higher eddy diffusivity in their study over Oklahoma City. The increased value of $e$ over London in the reference and notopo experiment is primarily originated from a stronger buoyancy production of TKE during daytime. The contribution of wind shear to the production of TKE is visible during the night.

Shear production of TKE over London increases during the course of the night, due to the increase in wind shear (Fig. 9c, d). The increase is stronger during the second night because of the larger increase in wind speed between 1800 UTC 15 May 2019 and 0100 UTC 16 May 

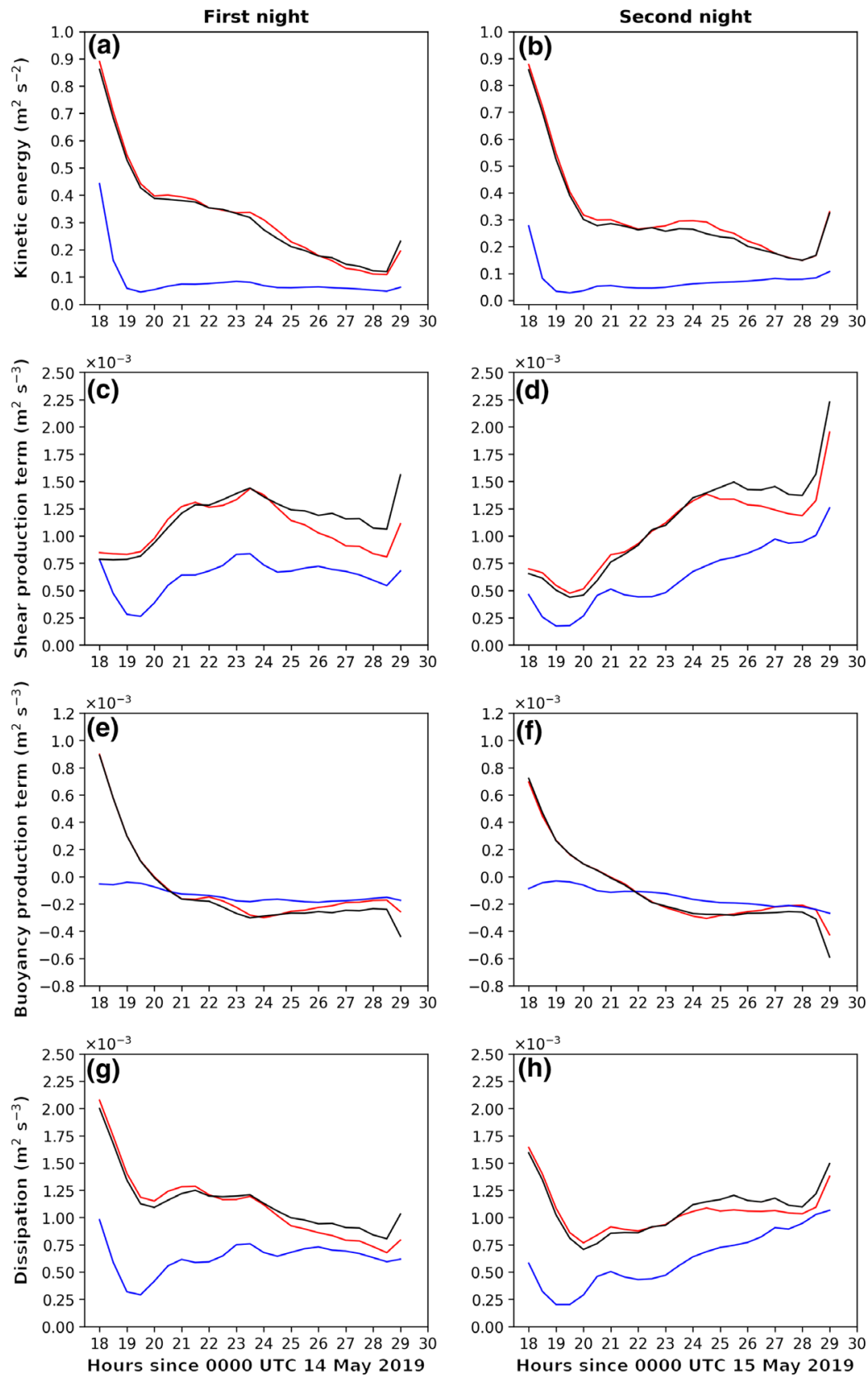

\section{Reference Cropland - Notopo}

Fig. 9 Average $e(\mathbf{a}, \mathbf{b})$, shear $(\mathbf{c}, \mathbf{d})$, and bouyancy $(\mathbf{e}, \mathbf{f})$ production of TKE, and dissipation $(\mathbf{g}, \mathbf{h})$ from WRF model between $50 \mathrm{~m}$ a.g.l until the boundary-layer top, averaged over an $30 \times 30 \mathrm{~km}^{2}$ area centred around London during the first (a, c, e, g) (1800 UTC 14 May 2019 to 0500 UTC 15 May 2019) and second night (b, d, f, h) (1800 UTC 15 May 2019 to 0500 UTC 16 May 2019) of the case study period for the reference (red), cropland (blue), and notopo (black) experiments 
2019 (Fig. 3a, b). Note that in the notopo experiment the shear production of TKE is larger after midnight. This might be due to larger wind shear (higher $U_{L L J}$ and lower $z_{L L J}$ values) in the notopo experiment compared to the reference (Fig. 8). A similar effect occurs in the cropland experiment, but the lower value of $e$ present within the boundary layer counteracts the effects of larger wind shear leading to lower shear production of TKE. The increase in shear production of TKE is the hours after sunset (2000 UTC to 0000 UTC) counteracts the destruction of TKE due to buoyancy suppression and dissipation, leading to a slower decay rate for TKE (Fig. 9e, f).

The effects of the LLJ-induced shear are prevalent over the urban area of London, due to the already higher TKE over London (Online Resource 21a, b) an affect of the higher buoyancy production of TKE over the urban area during daytime. Areas with high shear production of TKE are also present in the rural region south of London (Online Resource $21 \mathrm{a}, \mathrm{b})$, where wind shear within the boundary layer is large due to lower $z_{L L J}$ and higher $U_{L L J}$ compared to the other rural surroundings. This explanation is in agreement with the results of the notopo experiment (Sect. 7.2), that reveals higher $z_{L L J}$ values south of London.

\section{Discussion}

The WRF and UKV models are initialized at different times. An initialization time of 0900 UTC is not possible for the WRF model as the ECMWF operational analysis data are available every $6 \mathrm{~h}$. A comparison between the reference WRF run (initialized at $0000 \mathrm{UTC}$ ) and a run initialized at 0600 UTC showed a slightly worse performance at capturing the LLJ characteristics. Therefore we use 0000 UTC run as reference. The UKV model also utilizes a different model suite, is nested in a different global model, and uses data assimilation, while the WRF model is initialized with operational ECWMF analysis fields. These model differences make it difficult to meaningfully discuss the difference in LLJ characteristics between the two models. Yet, the fact that two independent model suites show a similar spatial distribution in LLJ characteristics over London and the same differences between the rural and the urban site strengthens our conclusions on the impact of urban areas on LLJs.

In our case study, the LLJ characteristics are strongly affected by the surrounding topography during both nights. This is in contrast to the findings of Banta et al. (2003) for the Cooperative Atmospheric Surface Exchange Study October 1999 (CASES-99), but elevation differences over the CASES-99 site were typically smaller than $50 \mathrm{~m}$, while terrain heights around London can exceed $300 \mathrm{~m}$ (Fig 2c). The topographic orientation with respect to the background flow might be important for the spatial distribution of LLJ characteristics (as seen in Banta et al. 2004). More case studies, with different background wind directions, are needed to test whether topographic effects on the LLJs are wind direction dependent. The complex topography around London and its proximity to the coast makes it very difficult to apply LLJ scaling approaches derived from studies over homogeneous and flat terrain (Banta et al. 2006; Klein et al. 2016), or to compare the results directly with more conceptual (Van de Wiel et al. 2010) and analytical LLJ models (Shapiro et al. 2016). This inhibits the comparison of the current results with those of the Joint Urban 2003 campaign over Oklahoma City (Wang et al. 2007; Lundquist and Mirocha 2008).

Section 6 shows an anti-correlation between spatial changes in $z_{L L J}$ and $U_{L L J}$ within and around London (Figs. $6 \mathrm{c}-\mathrm{f}$ and $7 \mathrm{c}-\mathrm{f}$ ). To test this hypothesis we performed correlation tests between the derivatives of the WRF-derived $U_{L L J}\left(\mathrm{~d} U_{L L J} / \mathrm{d} x\right)$ and $z_{L L J}\left(\mathrm{~d} z_{L L J} / \mathrm{d} x\right)$ across the $x$ (west-east) direction for the first $(r=-0.66, p<0.001)$ and second night 
$(r=-0.78, p<0.001)$. A similar, yet weaker, anti-correlation is reported along the $y$ (south-north) direction for the first $(r=-0.48, p<0.001)$ and second night $(r=$ $-0.50, p<0.001)$. We offer a few hypothesises that explain this anti-correlation, which address both orographic and urban effects.

Regarding the topographic effects, we hypothesize that the increase in terrain elevation represents an obstacle that the flow has to overcome. Under stable atmospheric conditions, the high-momentum jet layer must ascend (increase in $z_{L L J}$ ) over the topography. To conserve the flow energy, the flow must decelerate (decrease in $U_{L L J}$ ) according to Bernoulli's equation. In the leeward side of the mountain, the flow descends and gains momentum. The ascending motion and descending air motion at the windward and leeward side of the topography are also visible in Online Resource 18 and hints to the presence of gravity waves (discussed in Sect. 7.2). The higher TKE during the night over the urban area, caused by larger buoyancy during daytime, results in more turbulent drag over the city than over the surrounding rural areas. As the high momentum of the jet layer is advected from areas with lower TKE (less turbulent drag - lower boundary-layer height) to areas with higher TKE (more turbulent drag — higher boundary-layer height) the increase in turbulent drag decelerates the jet flow (lower $U_{L L J}$ ) (see Sect. 6.1). The change in vertical profile of the wind speed can also affect the $z_{L L J}$. This LLJ flow behaviour has been observed over Oklahoma city (Wang et al. 2007), and would be consistent with the findings of (Klein et al. 2016).

The changes in the shear production of TKE over the urban area are derived solely through the WRF simulations and should be handled with care. Thus, it is not possible to confirm the effects of wind shear on the TKE in the nocturnal UBL. As the shear production of TKE in the WRF model is dependent on the mixing length and the TKE itself, it is also likely that other processes (i.e., advection) might contribute to the increase in shear production of TKE after sunset. Thus the effect of the shear production of TKE in the UBL needs to be tested further with an eddy-resolving model (e.g. an LES model).

During the Joint Urban 2003 campaign over Oklahoma City, Lundquist and Mirocha (2008) reported LLJ cases that exhibit an 'upside-down' turbulent structure in the nocturnal UBL with turbulent motions driven by the shear generated under the LLJ nose. Similar evidence has been presented by Banta et al. (2006) for the CASES99 campaign. However, we do not find any consistent evidence of similar turbulent structure in the nocturnal UBL over London using the value of $e$ derived with the WRF model or the vertical velocity variance and skewness from the Doppler lidar. The generally lower $U_{L L J}\left(10 \mathrm{~m} \mathrm{~s}^{-1}\right)$ during our case study could be the reason for the lack of 'upside-down' UBL structure, as Banta et al. (2006) reported that this effect usually occurred when the wind speed was larger than $15 \mathrm{~m} \mathrm{~s}^{-1}$.

\section{Conclusions}

We investigate the interactions between LLJs and the nocturnal urban boundary layer during a 60-h case study period over London. Two Doppler lidars, in combination with two NWP models (WRF and UKV) are used to identify differences in the LLJ occurrence frequency and characteristics (fall-off, height, speed) between an urban (London) and a rural (Chilbolton) site. Two idealized WRF experiments are used to isolate urban and non-urban (i.e. topographic) effects on the LLJs. Moreover, the impact of the LLJ on shear production of TKE in the nocturnal UBL is analyzed using the WRF model and two sensitivity experiments.

Both models were able to capture the timing and characteristics of the LLJs, but dissipated the LLJ earlier than observed, causing a negative bias in jet speed. Moreover, both models 
had difficulties capturing the residual-layer wind speed, causing a bias in the fall-off speed. Low-level jets over London were located 60-90 m a.g.l. higher than over Chilbolton. This difference was observed using the Doppler lidar and was also simulated by both models. The difference in $U_{L L J}$ between the two sites is large during the first night $\left(2 \mathrm{~m} \mathrm{~s}^{-1}\right)$, but smaller during the second night $\left(<0.3 \mathrm{~m} \mathrm{~s}^{-1}\right)$.

Through a series of sensitivity tests we identified that: a) the topography around London has a stronger impact on LLJ characteristics than the urban-related processes, b) but the urban area has a significant impact on LLJs over the city and in the downwind urban areas due to urban plume effects. We find that increased turbulent mixing over the urban area of London increases the value of $z_{L L J}$ and decreases the value of $U_{L L J}$ not only over the urban area but also in the rural areas downwind of the city (up to a distance of $20 \mathrm{~km}$ ). Our results suggest that it is essential to isolate urban from non-urban processes on the LLJ over cities with moderate topographic surroundings.

Finally, we find that shear production of TKE within the boundary layer increases during the course of the night due to the increase in wind shear. The increase in shear production of TKE results in a slower decay rate of TKE. This indicates that the LLJ together with nocturnal heat release from the urban surface could delay the collapse of the UBL and maintain part of the turbulent mixing in the nocturnal UBL.

Supplementary Information The online version contains supplementary material available at https://doi. org/10.1007/s10546-021-00681-7.

Acknowledgements This research has been funded by the NWO Grant No. 864.14.007. The authors would like to thank the ECMWF for providing operational analysis data used for model initialization and forcing. We would also like to thank the UK Met Office and Humphrey Lean for providing operational data from the UKV model used in the research. Data availability statement: the data underlying this study are available upon request to the first author.

Open Access This article is licensed under a Creative Commons Attribution 4.0 International License, which permits use, sharing, adaptation, distribution and reproduction in any medium or format, as long as you give appropriate credit to the original author(s) and the source, provide a link to the Creative Commons licence, and indicate if changes were made. The images or other third party material in this article are included in the article's Creative Commons licence, unless indicated otherwise in a credit line to the material. If material is not included in the article's Creative Commons licence and your intended use is not permitted by statutory regulation or exceeds the permitted use, you will need to obtain permission directly from the copyright holder. To view a copy of this licence, visit http://creativecommons.org/licenses/by/4.0/.

\section{References}

Arnfield AJ (2003) Two decades of urban climate research: a review of turbulence, exchanges of energy and water, and the urban heat Island. Int J Climatol 23(1):1-26

Baas P, Bosveld FC, Klein Baltink H, Holtslag AAM (2009) A climatology of nocturnal low-level jets at Cabauw. J Appl Meteorol Clim 48(8):1627-1642

Banakh V, Smalikho I (2018) Lidar studies of wind turbulence in the stable atmospheric boundary layer. Remote Sens 10(8):1219

Banta R, Darby L, Fast J, Pinto J, Whiteman C, Shaw W, Orr B (2004) Nocturnal low-level jet in a mountain basin complex. Part I: evolution and effects on local flows. J Appl Meteorol 43(10):1348-1365

Banta RM, Pichugina YL, Newsom RK (2003) Relationship between low-level jet properties and turbulence kinetic energy in the nocturnal stable boundary layer. J Atmos Sci 60(20):2549-2555

Banta RM, Pichugina YL, Brewer WA (2006) Turbulent velocity-variance profiles in the stable boundary layer generated by a nocturnal low-level jet. J Atmos Sci 63(11):2700-2719

Barlow JF (2014) Progress in observing and modelling the urban boundary layer. Urban Clim 10:216-240 
Barlow JF, Halios CH, Lane SE, Wood CR (2015) Observations of urban boundary layer structure during a strong urban heat island event. Environ Fluid Mech 15:373-398

Best MJ, Pryor M, Clark DB, Rooney GG, Essery RLH, Ménard CB, Edwards JM, Hendry MA, Porson A, Gedney N, Mercado LM, Sitch S, Blyth E, Boucher O, Cox PM, Grimmond CSB, Harding RJ (2011) The joint UK land environment simulator (JULES), model description. Part 1: energy and water fluxes. Geosci Model Dev 4(3):677-699

Blackadar AK (1957) Boundary layer wind maxima and their significance for the growth of nocturnal inversions. Bull Am Meteorol Soc 38(5):283-290

Bohnenstengel S, Hamilton I, Davies M, Belcher S (2014) Impact of anthropogenic heat emissions on London's temperatures. Q J R Meteorol Soc 140(679):687-698

Boutle I, Eyre J, Lock A (2014) Seamless stratocumulus simulation across the turbulent gray zone. Mon Weather Rev 142(4):1655-1668

Chen F, Dudhia J (2001) Coupling an advanced land surface-hydrology model with the Penn State-NCAR MM5 modeling system. Part I: model implementation and sensitivity. Mon Weather Rev 129(4):569-585

Chen F, Kusaka H, Bornstein R, Ching J, Grimmond C, Grossman-Clarke S, Loridan T, Manning K, Martilli A, Miao S, Sailor D, Salamanca F, Taha H, Tewari M, Wang X, Wyszogrodzki A, Zhang C (2011) The integrated WRF/urban modelling system: development, evaluation, and applications to urban environmental problems. Int J Climatol 31(2):273-288

Halios CH, Barlow JF (2018) Observations of the morning development of the urban boundary layer over London, UK, taken during the ACTUAL project. Boundary-Layer Meteorol 166(3):395-422

Harman IN, Barlow JF, Belcher SE (2004) Scalar fluxes from urban street canyons. Part II: model. BoundaryLayer Meteorol 113(3):387-410

Holton JR (1967) The diurnal boundary layer wind oscillation above sloping terrain. Tellus 19(2):200-205

Hu XM, Klein P, Xue M, Lundquist J, Zhang F, Qi Y (2013) Impact of low-level jets on the nocturnal urban heat island intensity in Oklahoma City. J Appl Meteorol Clim 52(8):1779-1802

Iacono MJ, Delamere JS, Mlawer EJ, Shephard MW, Clough SA, Collins WD (2008) Radiative forcing by long-lived greenhouse gases: calculations with the AER radiative transfer models. J Geophys Res Atmos 113(D13103)

Jimenez PA, Dudhia J, Gonzalez-Rouco JF, Navarro J, Montávez JP, García-Bustamante E (2012) A revised scheme for the WRF surface layer formulation. Mon Weather Rev 140(3):898-918

Kallistratova MA, Kouznetsov RD (2012) Low-level jets in the Moscow region in summer and winter observed with a Sodar network. Boundary-Layer Meteorol 143:159-175

Kalverla P, Steeneveld GJ, Ronda R, Holtslag AA (2019) Evaluation of three mainstream numerical weather prediction models with observations from meteorological mast IJmuiden at the North Sea. Wind Energy 22(1):34-48

Kalverla PC, Steeneveld GJ, Ronda RJ, Holtslag AA (2017) An observational climatology of anomalous wind events at offshore meteomast IJmuiden (North Sea). Wind Eng Ind Aerodyn 165:86-99

Kalverla PC, Duncan JB Jr, Steeneveld GJ, Holtslag AAM (2019) Low-level jets over the North Sea based on ERA5 and observations: together they do better. Wind Energy Sci 4(2):193-209

Klein P, Hu X, Shapiro A, Xue M (2016) Linkages between boundary-layer structure and the development of nocturnal low-level jets in central Oklahoma. Boundary-Layer Meteorol 158(3):383-408

Kotroni V, Lagouvardos K (1993) Low-level jet streams associated with atmospheric cold fronts: seven case studies from the FRONTS 87 experiment. Geophys Res Lett 20(13):1371-1374

Kusaka H, Kondo H, Kikegawa Y, Kimura F (2001) A simple single-layer urban canopy model for atmospheric models: comparison with multi-layer and slab models. Boundary-Layer Meteorol 101(3):329-358

Lapworth A, Claxton B, McGregor J (2016) The effect of gravity wave drag on near-surface winds and wind profiles in the nocturnal boundary layer over land. Boundary-Layer Meteorol 156(2):325-335

Lemonsu A, Belair S, Mailhot J (2009) The new Canadian urban modelling system: evaluation for two cases from the joint urban 2003 Oklahoma City experiment. Boundary-Layer Meteorol 133(1):47-79

Lock A, Brown A, Bush M, Martin G, Smith R (2000) A new boundary layer mixing scheme. Part I: scheme description and single-column model tests. Mon Weather Rev 128(9):3187-3199

Lundquist J, Mirocha J (2008) Interaction of nocturnal low-level jets with urban geometries as seen in joint urban 2003 data. J Appl Meteorol Clim 47(1):44-58

Manninen AJ, O'Connor EJ, Vakkari V, Petäjä T (2016) A generalised background correction algorithm for a halo doppler lidar and its application to data from Finland. Atmos Meas Tech 9(2):817-827

Manninen AJ, Marke T, Tuononen M, O’Connor EJ (2018) Atmospheric boundary layer classification with doppler lidar. J Geophys Res Atmos 123(15):8172-8189

Mikio N, Hiroshi N (2009) Development of an improved turbulence closure model for the atmospheric boundary layer. J Meteorol Soc Jpn 87(5):895-912 
Olson J, Jaymes S, Wayne M, John M, Mariusz P, Kay S (2019) A description of the mynn-edmf scheme and the coupling to other components in WRF-ARW. NOAA technical memorandum oar GSD 61, pp 37

Pal S, Xueref-Remy I, Ammoura L, Chazette P, Gibert F, Royer P, Dieudonne E, Dupont JC, Haeffelin M, Lac C, Lopez M, Morille Y, Ravetta F (2012) Spatio-temporal variability of the atmospheric boundary layer depth over the Paris agglomeration: an assessment of the impact of the urban heat island intensity. Atmos Environ 63:261-275

Park J, Basu S, Manuel L (2014) Large-eddy simulation of stable boundary layer turbulence and estimation of associated wind turbine loads. Wind Energy 17(3):359-384

Pichugina YL, Banta RM (2010) Stable boundary layer depth from high-resolution measurements of the mean wind profile. J Appl Meteorol Clim 49(1):20-35

Porson A, Clark PA, Harman I, Best M, Belcher S (2010) Implementation of a new urban energy budget scheme in the metum. Part I: description and idealized simulations. Q J R Meteorol Soc 136(651):1514-1529

Shapiro A, Fedorovich E, Rahimi S (2016) A unified theory for the great plains nocturnal low-level jet. J Atmos Sci 73(8):3037-3057

Skamarock WC, Klemp JB, Dudhia J, Gill DO, Liu Z, Berner J, Wang W, Powers JG, Duda MG, Barker DM, Huang XY (2019) A description of the advanced research WRF version 4. NCAR tech. note ncar/tn$556+$ str

Smith R (1990) A scheme for predicting layer clouds and their water content in a general circulation model. Q J R Meteorol Soc 116(492):435-460

Steeneveld G, Holtslag A, Nappo C, van de Wiel B, Mahrt L (2008) Exploring the possible role of small-scale terrain drag on stable boundary layers over land. J Appl Meteorol Clim 47(10):2518-2530

Storm B, Dudhia J, Basu S, Swift A, Giammanco I (2009) Evaluation of the weather research and forecasting model on forecasting low-level jets: implications for wind energy. Wind Energy 12(1):81-90

Theeuwes NE, Barlow JF, Teuling AJ, Grimmond CSB, Kotthaus S (2019) Persistent cloud cover over megacities linked to surface heat release. NPJ Clim Atmos Sci 2(1):1-6

Thompson G, Field PR, Rasmussen RM, Hall WD (2008) Explicit forecasts of winter precipitation using an improved bulk microphysics scheme. Part II: implementation of a new snow parameterization. Mon Weather Rev 136(12):5095-5115

Vakkari V, Manninen AJ, O’Connor EJ, Schween JH, van Zyl PG, Marinou E (2019) A novel post-processing algorithm for halo doppler lidars. Atmos Meas Tech 12(2):839-852

Vanderwende B, Lundquist J, Rhodes M, Takle E, Irvin S (2015) Observing and simulating the summertime low-level jet in central Iowa. Mon Weather Rev 143(6):2319-2336

Wang Y, Klipp C, Garvey D, Ligon D, Williamson C, Chang S, Newsom R, Calhoun R (2007) Nocturnal low-level-jet-dominated atmospheric boundary layer observed by a doppler lidar over Oklahoma City during JU2003. J Appl Meteorol Clim 46(12):2098-2109

Van de Wiel BJH, Moene AF, Steeneveld GJ, Baas P, Bosveld FC, Holtslag AAM (2010) A conceptual view on inertial oscillations and nocturnal low-level jets. J Atmos Sci 67(8):2679-2689

Wood CR, Lacser A, Barlow JF, Padhra A, Belcher SE, Nemitz E, Helfter C, Famulari D, Grimmond CSB (2010) Turbulent flow at $190 \mathrm{~m}$ height above London during 2006-2008: a climatology and the applicability of similarity theory. Boundary-Layer Meteorol 137:77-96

Zhang C, Wang Y, Hamilton K (2011) Improved representation of boundary layer clouds over the southeast pacific in ARW-WRF using a modified Tiedtke cumulus parameterization scheme. Mon Weather Rev 139(11):3489-3513

Publisher's Note Springer Nature remains neutral with regard to jurisdictional claims in published maps and institutional affiliations. 